\title{
A hazai publikált óvoda-iskola átmenetet segítő gyakorlatok szisztematikus áttekintése
}

\author{
Fleisz-Gyurcsik Anita \\ Szegedi Tudományegyetem Neveléstudományi Doktori Iskola
}

\begin{abstract}
Absztrakt
Az óvoda-iskola átmenet megkönnyítésére a nemzetközi és a hazai szakirodalom számos gyakorlatot ismertet, ezek hazai kutatói reflexiója azonban még nem ismert. Ezért az áttekintésünk célja a hazai óvoda-iskola átmenetet segítő publikált gyakorlatok összegyüjtése, rendszerezése és elemzése. A tanulmányunkban a 2020 márciusáig megjelent hazai szakirodalomban 42 gyakorlatot azonosítottunk, ezeket hét szempont alapján elemeztük. Így láthatóvá vált, hogy a legtöbbet gyakorló pedagógusok dolgozták ki, s a 2000-es évek közepén tették közzé. Leginkább az új intézmény és a leendő tanítók megismertetésére irányulnak. Legjellemzőbb, hogy a szerzők nem ágyazzák be a munkájukat elméleti kontextusba. A működésükben inkább a személyi feltételek hangsúlyosak, mint a tárgyi-környezeti feltételek. A fellelt gyakorlatok eltérő hosszúságú intervallumot ölelnek fel az átmenetből; a leggyakoribb az óvodai nagycsoport teljes tanévére kiterjedő óvoda-iskola átmenetet segítő gyakorlat. A legtöbb gyakorlat esetében nem találtunk utalást hatásvizsgálatra.
\end{abstract}

Kulcsszavak: óvoda-iskola átmenet, iskolakezdés, szisztematikus áttekintés

\section{Bevezetés}

Régóta igazoltnak tekinti a tanítás-tanulás kutatása, hogy kulcsfontosságú a kisgyermekkori fejlődés megsegítése. Például Heckman és munkatársainak (2006) gazdasági elemzése kimutatta, hogy az ebben az időszakban történő beruházások társadalmi-gazdasági megtérüléshez vezetnek hosszú távon. Duncan és munkatársai (2007), illetve Józsa és munkatársai (2019) longitudinális vizsgálatokkal igazolták, hogy az egyes képességterületek iskolakezdéskori fejlettsége szignifikánsan befolyásolja a későbbi tanulmányi teljesítményt, míg fontos szociokulturális változók hatása messze elmarad ettől. A Diagnosztikus Fejlődésvizsgáló és Kritériumorientált Fejlesztő Rendszer (továbbiakban: DIFER) programcsomag tesztjeivel végzett longitudinális vizsgálatok (például Józsa, 2004) eredményei felhívták arra a figyelmet, hogy az iskolát átlagos óvodai középső-, illetve nagycsoportos fejlettségi szinttel 
megkezdő gyermekek többsége lemarad azoktól az osztálytásaitól, akik az iskolát megfelelő (átlagosnál magasabb) fejlettségi szinttel kezdik. Ugyanakkor az óvoda és az iskola intézménye, a két tanulási környezet között több jól érzékelhető különbség is van, melyek szintén megnehezítik az átmenetet (például Kende \& Illés, 2007). Az óvoda-iskola átmenet, a sikeres iskolakezdés elősegítése a kisgyermekkori fejlődés támogatásának látványos eleme, amely régóta egyaránt foglalkoztatja a gyakorló pedagógusokat és a szülőket is.

Az óvoda-iskola átmenet megkönnyítésére a nemzetközi és a hazai szakirodalom (például Fisher, 2011; Sóstói, 2002) számos gyakorlatot ismertet. A nemzetközi kontextus a jelen tanulmány esetében viszonylag kevés viszonyítási pontot kínál, mivel a különböző országok oktatási rendszereinek felépítése eltérő, így az is nagymértékben különbözik, hogy a gyerekek mikor, milyen óvodai fejlesztés után és milyen körülmények között kezdik el az iskolát, a tartalmi szabályozás milyen célokat és feladatokat rendel az egyes intézményekhez. Noha a hazai szakirodalomban nem ritka az óvoda-iskola átmenet segítése céljából kidolgozott gyakorlatok közlése, ezek szisztematikus áttekintésére még nem került sor. İgy nincs átfogó képünk arról, hogyan próbálják az érintett pedagógusok az átmenetet segíteni. Miben hasonlítanak, miben térnek el egymástól a szélesebb szakmai közönség számára hozzáférhető gyakorlatok? Melyik megoldástól milyen eredményesség és hatékonyság várható?

Elméleti megfontolások arra vezethetnek, hogy az óvoda-iskola átmenet központi fogalmának az iskolaérettséget tekintsem - az átmenet tehát az ahhoz vezető folyamat, hogy a gyermek képessé, alkalmassá váljon iskolai tanulásra (vö. Mérei \& V. Binét, 1978; Nagy, 1980). Vajon a publikált gyakorlatok is ilyen tágan, fejlődéssegítésként értelmezik az átmenet során adódó feladatokat, vagy pedig szűkebben, csak az intézményváltásra összpontosítanak?

Jelen tanulmány célja tehát az óvoda-iskola átmenetet segítő hazai publikált gyakorlatok áttekintése és vizsgálata a céljaik és a hatékonyságukat biztosító elemek szempontjából. A tanulmányomban nem célom az egyes gyakorlatok részletes bemutatása. Áttekintésemben a gyakorlatok rendszerezése során az ábécérend elvét követem, mivel a gyakorlatok időbeliségét tekintve nem találtam tartalmi, lényegi mintázatokat, trendeket. Először a hazai óvodai nevelés és iskolai oktatás tartalmi szabályozását idézem fel, illetve az óvoda-iskola átmenet és az iskolaérettség meghatározásaival, majd a két intézmény közötti különbségekkel foglalkozom. A háttér felvázolása után a hazai publikált óvoda-iskola átmenetet segítő gyakorlatok összegyüjtési folyamatát ismertetem. Majd a gyakorlatok feltárásához kidolgozott elemzési szempontok mentén haladva tekintem át ezeket: (1) publikálás ideje; (2); kidolgozóik háttere, (3) megalapozottságuk, beágyazottságuk; (4) megcélzott területek, (5) müködési feltételeik, (6) lefedett időszak, illetve (7) hatásvizsgálat szempontjai mentén végzem az elemzést.

Az elemzési szempontrendszer kidolgozásakor elméleti megfontolásokra támaszkodtam. Egyrészt fontosnak tartottam áttekinteni a kisgyermekkori 
fejlődést leíró szakirodalmat, annak Nagy József (1980) óta kiemelkedő hazai eredményeit. Azt a hagyományt követtem, amely az átmenetet tágan értelmezi, az intézményváltást, valamint számos kritikus fejlődési folyamatot is figyelembe vesz az óvoda-iskola átmenet értelmezésében. Másrészt az átmenet segítését olyan pedagógiai beavatkozásnak tekintem, amelynek vizsgálható a tervezése, gyökerei; a célrendszere; a működése; és az eredményessége, hatásai, hatékonysága.

A feltárt gyakorlatok többsége gyakorló pedagógusok által kezdeményezett. Leginkább az új intézmény és a leendő tanítók megismertetésére összpontosítanak; az iskolaérettség és az egyéni fejlesztés kérdései kevésbé jelennek meg bennük. Eredményeim szerint a legjellemzőbbek az explicit megalapozottság nélküli gyakorlatok; kevésbé jellemző, hogy a szerzők elméleti keretbe ágyazzák a munkájukat; ritka a tartalmi szabályozás dokumentumaihoz kötött gyakorlat. Inkább személyi feltételeknek kell teljesülniük a müködésükhöz, mint tárgyi-környezeti feltételeknek. Változó hosszúságú időszakot ölelnek fel az átmenetből; a leggyakoribb az óvodai nagycsoport teljes tanévének lefedése. A gyakorlatok túlnyomó többségénél nem jelzik a szerzők hatásvizsgálat megtörténtét, eredményeit. Mindezek alapján látható, hogy a feltárt gyakorlatok többsége szűken értelmezi az óvoda-iskola átmenetet - vagyis kevésbé jellemző rájuk, hogy az intézményváltás mellett más kritikus fejlődési folyamatot figyelembe vennének. Ennek oka lehet az óvodai fejlesztés hatékonyságának eltérő értelmezése.

\section{Az óvodai nevelés és az iskolai oktatás szabályozása hazánkban}

A gyakorlatok vizsgálatához fontos felidéznem a két intézményre vonatkozó szabályozást. Az óvodai nevelésben hagyományosan részt vesznek Magyarországon a gyerekek. A közelmúltig az utolsó óvodai évfolyam látogatása volt kötelező, de már akkor is sok szülő (57 \%) élt a lehetőséggel, hogy három évig járjon a gyermeke ebbe az intézménybe (Török, 2004). A tanulmány írásakor hatályos törvény ${ }^{1} 2015$ szeptember elsejétől kezdődően kötelezővé teszi a részvételt legalább napi négy órában óvodai foglalkozáson a harmadik életév betöltése után. A magyarországi óvodák nevelési alapelveit az Óvodai Nevelés Országos Alapprogramja (2012; továbbiakban: Alapprogram) szabályozza. Ez az óvodai nevelés három fó feladatát határozza meg: (1) az egészséges életmód alakítását; (2) az érzelmi, erkölcsi és értékorientált közösségi nevelést; (3) valamint az anyanyelvi, értelmi fejlesztést és nevelést. A feladatok megvalósítását játékos, mozgásos tevékenységekbe ágyazva írja elő.

A 2019 előtti szabályozás szerint az iskolaérettség megállapításában aktív szerepe volt a gyermeket ismerő óvodapedagógusoknak, szülőknek és az intézményvezetőknek is, akik szakértői vizsgálatot is kérhettek arról, hogy a gyermek alkalmas-e az első osztály megkezdésére. Az iskolakezdés kezdeté-

${ }^{1}$ 2011. évi CXC. törvény a Nemzeti köznevelésről 8. \$ (2) bekezdése 
ről dönthetett: (a) az óvoda vezetője; (b) a szakértői bizottság iskolaérettségi vizsgálattal, amennyiben a gyermek nem járt óvodába; (c) a szakértői bizottság iskolaérettségi vizsgálattal az óvoda és/vagy iskola vezetője, vagy a szülő kezdeményezésére ${ }^{2}$. Több összefoglaló tanulmány (vö. Gerebenné Várbíró \& Vidákovich, 1997; Apró, 2013; Gyurcsik et al., 2017) vetette össze a Magyarországon alkalmazott iskolaérettség-vizsgálati módszereket.

A 2011. évi köznevelési törvény ${ }^{3}$ a korábbi törvényi szabályozáshoz képest kisebb mozgásteret biztosít, mivel a gyermek „tankötelessé válik abban az évben, amelynek augusztus 31. napjáig a hatodik életévét betölti”. A szülö kérelmére az iskolakezdés kitolható vagy csökkenthető egy évvel - ezt a szülőnek kell kezdeményeznie az iskolakezdés évében január 15-éig az engedélyező szervnél (Oktatási Hivatal), az eljárás pedig egy szakértői bizottság kompetenciája.

Magyarországon az Alapprogram (2012) részletesen, külön fejezetekben tárgyalja a tipikus fejlettség jellemzőit az óvodáskor végén. Három területet különböztet meg: (1) a testi; (2) a lelki; és (3) a szociális érettséget. A testi érettség feltételei közé sorolja a test átalakulását, az összerendezett, harmonikus finom- és nagymozgásokat, valamint a szükségletek kielégítésének szándékos irányítását. A lelki érettség jellemzői közé sorolja a megfelelő fejlettségű kognitív képességeket, a gyermek alapvető ismereteit a környezetéről és önmagáról, illetve a nyitottságot és az érdeklődést. A szociálisan érett gyermek sajátosságai közé sorolja az együttmüködés és a kapcsolatteremtés képességét a társaival és a felnőttekkel egyaránt, a szabályokhoz való alkalmazkodás képességét, az önállóságot, a feladattudatot, a feladattartást és a feladatmegértést.

Az általános iskola indulószintje illeszkedik az Alapprogramban (2012) megfogalmazott óvodáskor végi fejlődés jellemzőihez (lásd Kerettanterv az általános iskola 1-4. évfolyama számára, n.d.). Az iskolai tantervek az első tanév első félévére előkészítő időszakként tekintenek, mely során a fö hangsúly a gyermekek megfigyelésére és ezek alapján a részképességek fejlesztésére helyeződik. Az első osztályban az óvodában megismert témakörök kiegészülnek újabb ismeretekkel és fokozatosan kezdődik el a nyelvi-irodalmi fogalmak megalkotásának előkészítése. A cél az, hogy az első tanév végéig a gyermekek megtanulják az írott kisbetűket olvasni és helyesen leírni. Fő feladat még a rendezett kézírás kialakítása és az ösztönös nyelvhasználat tudatosítása. A matematikai tanítás során az első osztályban a különböző témakörök megalapozása kerül előtérbe. A gyermekektől az első osztály első félévében még nem várható el az összefüggések felismerése, illetve megengedett a különböző eszközök használata a fejben számolás egyes lépéseinek megértéséhez. Az első osztály második felében kezdődik a zenei elemek tudatosítása (például az egyenletes lüktetés érzetének kialakítása), mely az óvodai neveléshez hasonlóan gyermekdalok éneklésével és eljátszásával történik.

${ }^{2} 2011$. évi köznevelési törvény 45. \$ 2

${ }^{3}$ módosított 45 . $\$ 2$. bekezdése 


\section{Az óvoda-iskola átmenet és az iskolaérettség fogalmának meghatározása}

Az átmenet az egyik környezetből a másikba kerülést, az egyik nevelési-oktatási szintből a másikba történő váltást jelenti (Fabian, 2007). Ezen belül az óvoda-iskola átmenetet a Pedagógiai Lexikon ötéves kortól hét-nyolc éves korig terjedő időszakként definiálja, amelynek központi kérdése az iskolaérettség (Páli, 1997).

Britto (2012, p. 8) szerint az átmenet három folyamat eredménye: „a gyerekek új tanulási környezetekbe lépnek és alkalmazkodnak azokhoz, a családok megtanulnak együttmüködni egy szociokulturális rendszerrel [a formális oktatással], és az iskolák megteszik a megfelelő lépéseket az egyéni és társadalmi sokszínűséget képviselő gyerekek bevezetésére ebbe a rendszerbe”. Ahogyan ez a megfogalmazás érzékelteti, mindhárom szereplő esetében új tudást hoz létre ez a folyamat. Britto egy nemzetközi összehasonlító vizsgálatban az iskolaérettség-definíciókat vizsgálva is azonosította ezt a három dimenziót: (1) a gyerekek, (2) az iskola, valamint (3) a család és a közösség felkészültségét az iskolakezdésre (Britto, 2012, p. 6-8). A szerző két fogalmat tekint vizsgálandónak az iskolaérettség elemzésekor a három dimenzió mentén: az átmenetet és a kompetenciafejlődést.

Meisels (1999 idézi Dockett \& Perry, 2002) az iskolaérettség kialakulásának négyféle elméleti megközelítését azonosította. Szerinte az iskolaérettség kialakulása (1) a biológiai érés eredménye - az iskolaéretté válás folyamata nem gyorsítható, időre van szükség ahhoz, hogy a gyermekek a különböző fejlődési szakaszok sorozatán keresztül haladva megérjenek az iskolára; (2) a gyermek tudásának és viselkedésének eredménye - az iskolaérettség egy végpont; a gyermek vagy készen áll az iskolára, vagy nem; amennyiben nem áll készen, a hiányzó készségek és ismeretek megtaníthatók; (3) a közösség, annak értékeinek és elvárásainak eredménye - az iskolaérettség jelentése a különböző közösségekben más és más, így előfordulhat, hogy az egyik iskolában iskolaérettnek minősül a gyermek, míg a másikban nem; a társadalom, a család és az iskola közösen határozza meg az iskolaérettség kritériumait; (4) kölcsönhatás eredménye - az iskolaérettség egy kölcsönhatás a gyermek előzetes tudása és ismeretei, a genetikai adottságai, az érési állapota, illetve a környezeti és a kulturális tapasztalatai között (Meisels 1999 idézi Dockett \& Perry, 2002).

A nemzetközi és a hazai szakirodalomban a sikeres iskolakezdést több, egymással szorosan összefüggő terület határozza meg. Az áttekintett szakirodalom alapján a sikeres iskolakezdést leginkább a kognitív képességek megfelelő fejlettsége határozza meg. Ezen belül az általános tudás (például a tárgyak tulajdonságainak ismerte; a tárgyak közötti hasonlóságok és különbségek felismerése; a gyermek általános tudása önmagáról és a közvetlen környezetéről) és a nyelvi fejlettség (például gondolatok, ismeretek, tapasztalatok érthető és gördülékeny kifejezése; a történetek, a mesék összefüggé- 
seinek megértése) tűnik a legfontosabbnak. Az iskolakezdést meghatározó tényezők között nagy szerep jut a szociális és érzelmi képességek megfelelő szintű fejlettségének is. Ezen belül a kapcsolatkialakítás képessége, a feladattartás és a feladatvállalás tủnik a legfontosabbnak. A motoros, illetve a fizikai-testi terület kevésbé tünik hangsúlyosnak (Commodari, 2013; Hair et al. 2006; Kagan et al. 1995; Wesley \& Buysse, 2003; Mérei \& V. Binét, 1978; Nagy, 1980).

A hazai kutatók körében előfordul, hogy az iskolaérettség fogalma helyett más fogalmakat használnak, ugyanakkor ezek között csak szemléletbeli különbségek húzódnak meg. Például Mérei Ferenc \& V. Binét Ágnes (1978) az iskolaérettség helyett az iskolára való alkalmasság fogalmát használta, amely magába foglalja a helyzetmegértést, a feladattudatot, a kitartást, az értelmi képességeket és a testi fejlettséget is. Nagy József (1980) munkáiban az iskolakészültség fogalma jelenik meg, mivel beiskolázási kritériumként az iskolára való magatartásbeli és tudásbeli felkészültséget tekinti.

A nemzetközi és a hazai kutatások igazolják az iskolaérettség társadalmi meghatározottságát (például Zill \& West, 2001; Kende, 2008). Józsa Krisztián (2004), illetve Józsa Krisztián és Zentai Gabriella (2007a; 2007b) kutatási eredményei azt mutatják, hogy a szülők iskolai végzettsége szoros kapcsolatban áll a gyermekek elemi alapkészségeinek fejlettségével - vagyis a kevesebb, mint nyolc általános iskolát végzett anyák és az egyetemi végzettségű anyák gyermekei között akár kétévnyi fejlettségbeli különbség is lehet. Ugyanakkor különböző longitudinális kutatások (például Duncan et al., 2007; Józsa et al., 2019) eredményei rávilágítottak arra, hogy a különböző szociokulturális változók (mint a szülők iskolai végzettsége) nem közvetlenül hatnak a későbbi tanulmányi teljesítményre, míg az egyes képességterületek iskolába lépéskori fejlettsége szignifikánsan befolyásolja azt. Fejlesztőkísérletek eredményei igazolják (vö. Józsa \& Zentai, 2007a; 2007b; Zentai \& Józsa, 2012), hogy a hátrányos helyzetből fakadó lemaradás játékos fejlesztéssel csökkenthető.

\section{A két intézmény közötti különbségek rendszerezése}

Több szerző rendszerezte már az óvoda és az iskola közötti különbségeket. Ezek közül csupán a vizsgálat szempontjából legfontosabbakat emelem ki.

Az alaptevékenység megváltozása - az iskola első osztályában a játékos, mozgásos tevékenységformákat és tanulást, felváltja a szándékos tanulás. Továbbá az óvodai nevelés során a gyermekek eldönthetik, hogy mit, hogyan és meddig játszanak, illetve melyik foglalkozáson szeretnének részt venni, ezzel szemben az iskolában kötelező jellegü, 45 perces tanítási órák vannak. Az óvodában az alapkészségek fejlesztése lassú tempóban zajlik, melyet az iskolában feszített tanulási tempó és határozott időkeret vált fel. Az iskolában jelenik meg az írásbeliség (például Veszprémi \& Solymos, 2005; Perlai, 2009; Kolátné Kovács \& Kormosné Kovács, 2015). Megváltozik a környezet - a gyermekek új környezetbe kerülnek, ahol új, még nem nagyon ismert 
felnőttek és gyermekek veszik őket körbe (például Kiss \& Szabóné Kálmán, 2002; Pászti, 2007). Az elvárásrendszer átalakul - az iskolában a teljesítményorientáció kerül előtérbe. Ezenfelül az óvodában a formatív visszajelzés a hangsúlyos, melynek célja a tanulási folyamatok segítése, a megerősítés és a személyiség kibontakoztatása, míg az iskolában leginkább a szummatív értékelés jellemző, melynek célja a tanulók teljesítményének értékelése. Továbbá az iskolában a gyerekeknek új, szigorú, kötött szabályrendszert kell követniük (például Ligeti, 2000; Kende \& Illés, 2007; Alapprogram, 2012; NAT, 2012; Golyán, 2013).

Elméleti áttekintésem fó tanulságai közé tartozik, hogy a hazai és a nemzetközi szakirodalom az óvoda-iskola átmenet központi kérdésének az iskolaérettséget tekinti. A sikeres iskolakezdést négy egymással szorosan öszszefüggő terület határozza meg. Az óvoda és az iskola közötti különbségek rendszerezése rávilágított arra, hogy számos tényező megnehezíti az átmenetet.

\section{A hazai publikált óvoda-iskola átmenetet segítő gyakorlatok kiválasztási folyamata és az elemzési szempontok}

A hazai publikált óvoda-iskola átmenetet segítő gyakorlatok azonosításához néhány főbb tudományos adatbázisban (EPA, HUMANUS, MATARKA, OPKM), illetve az Educatio Társadalmi Szolgáltató Nonprofit Kft. Iskolatáska jógyakorlat-gyűjteményében kerestem. A keresés során az alábbi keresőkifejezéseket használtam: „óvoda-iskola átmenet”; „óvoda vége”; „iskola kezdő szakasza”, „iskola-előkészítés”; „iskolakezdés”. Tanulmányomban a 2020 márciusáig publikált gyakorlatokat vizsgálom. Ezekkel a keresési beállításokkal összesen 300 publikációt találtam, amelyek témái tág körben szóródtak. Csak azokat a munkákat választottam ki, amelyeknek a céljai és a tartalmai a hatékony óvoda-iskola átmenet támogatására irányulnak, és amelyek koherens programot mutatnak be.

A magyar szakirodalomból ismert Kerekes és munkatársainak (2011) gyakorlat- meghatározása: „a gyakorlat a köznevelés különböző területein alkalmazott, egyéni vagy intézményi szinten megjelenő, szemléletében és gyakorlatában innovatív módszer, tevékenység, eszközhasználat, pedagógiai vagy szervezetfejlesztési gyakorlat vagy ezek együttese, amely a köznevelési intézmény müködésében megtapasztalható és az intézmény nevelési-oktatási vagy szakszolgálati feladatainak ellátását pozitívan befolyásolja" (Kerekes et al., 11). Koherens programnak azokat a gyakorlatokat tekintettem, amelyek összefüggö, kidolgozott eszközrendszerrel próbálják segíteni az óvoda-iskola átmenetet. Így nem került be a válogatásba például olyan gyűjtemény, amely egymástól lényegében különálló, válogatható, kombinálható módszertani tanácsokat ad (vö. Golyán, 2013). Így eddig összesen 42 publikált hazai gyakorlatot azonosítottam (1. ábra), melyeket hét szempont alapján elemeztem: (1) Mikor közölték a szerzők a gyakorlataikat? (2) Kik 
érzékelnek megoldandó problémát az óvoda-iskola átmenet során, amelyet pedagógiai beavatkozással kezelni lehet? Kik érzik fontosnak, hogy erről a beavatkozásról beszámoljanak a szakmai közvélemény számára? (3) Menynyire kötődnek az óvoda-iskola átmenet észlelt problémáit kezelni kívánó gyakorlatok e problémák alapos feltárásához, akár tudományos igényü értelmezéséhez? (4) Mire irányulnak, mit kívánnak fejleszteni a gyakorlatok? (5) Mit igényelnek az egyes gyakorlatok? Milyen személyi és környezeti-tárgyi feltételek szükségesek a működésükhöz? (6) Milyen időintervallumot fednek le az átmenetből? (7) Feltárták-e a hatékonyságát? Milyen hatást ért el a gyakorlat alkalmazása során a célcsoport vonatkozásában?

\section{1. ábra}

A kutatási mintába került óvoda-iskola átmenetet könnyitö programok kiválasztásának algoritmusa

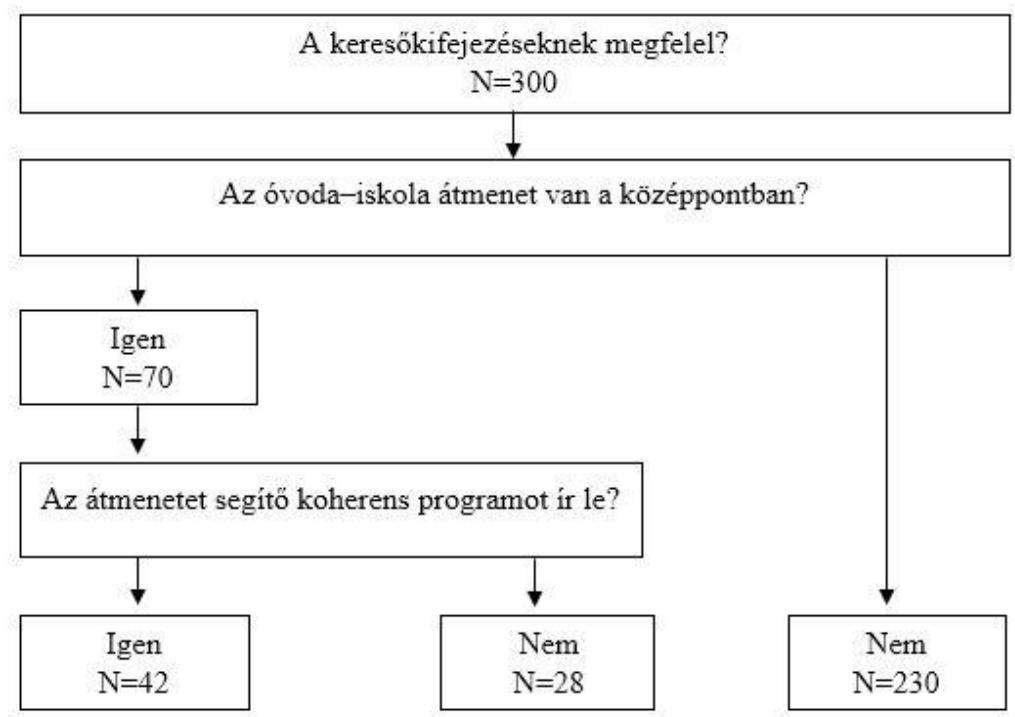

\section{Eredmények}

\section{A gyakorlatok publikálási ideje}

Az 1. táblázat bemutatja a vizsgált publikációk időbeli eloszlását. A legkorábbi beszámoló 1984-ből való. A legtöbb 1995-1999, illetve 2010-2015 közötti időszakban jelent meg. Ezeknek az okai lehetnek oktatáspolitikai változások. Az 1993-as LXXIX. közoktatási törvény 24. \$ (1) alapján az óvoda hároméves kortól fogadja a gyerekeket; illetve bevezette az óvoda iskola-előkészítő szerepét, ugyanis ötéves kortól kötelezővé tette a napi négyórás óvodai nevelést. 
Ezenfelül nagy változást jelentett az, hogy bevezette az óvodai pedagógiai programokat, melyeket az óvodák önállóan összeállíthattak vagy a központilag kidolgozott programok közül választhattak. Ezt követően megjelent az 1996-os Alapprogram, mely gyermekközpontú, játék- és tevékenységalapú dokumentum (Molnár et al., 2015). A 2011. évi CXC. törvény a nemzeti köznevelésről $5 . \mathbb{S}(1)$ kötelezővé tette hároméves kortól az óvodai nevelést. Majd az Alapprogram (2012) megerősítette az óvodai nevelés hagyományait

\section{1. táblázat}

Az összegyüjtött publikált gyakorlatok időbeli eloszlása

\begin{tabular}{|c|c|c|c|c|c|c|c|}
\hline & \multicolumn{7}{|c|}{ Megjelenés } \\
\hline & $\begin{array}{l}1984- \\
1989\end{array}$ & $\begin{array}{l}1990- \\
1994\end{array}$ & $\begin{array}{l}1995- \\
1999\end{array}$ & $\begin{array}{c}2000- \\
2004\end{array}$ & $\begin{array}{l}2005- \\
2009\end{array}$ & $\begin{array}{l}2010- \\
2015\end{array}$ & $\begin{array}{l}2016- \\
2020\end{array}$ \\
\hline $\begin{array}{l}\text { Gyakorlatok } \\
\text { száma }\end{array}$ & 1 & 5 & 8 & 6 & 3 & 14 & 5 \\
\hline
\end{tabular}

\section{A gyakorlatok kidolgozói}

A publikációkban közölt információk szerint a szerzők között meghatározóak az érintett gyakorló pedagógusok, összesen a vizsgált publikációkban 36 fö. 24 gyakorlatot tanító közölt; hat köthető óvodapedagógushoz. Meglepően kevés, további hat született óvodapedagógus és tanító együttmüködéséből. Egy gyakorlatot óvodapedagógus dolgozott ki gyógypedagógusok, fejlesztőpedagógusok és pszichológusok segítségével, illetve egyet iskolapszichológus közölt.

A kutatók által közölt gyakorlatok, átmenetet segítő fejlesztő programok - 4 ilyen került a mintába - kidolgozói között is vannak gyakorló óvodapedagógusok és tanítók. Ez a négy gyakorlat tehát kutatói és gyakorlati szakemberek közös munkájával született. Ezek közül három eredeti fejlesztés: a DIFER Programcsomag (Nagy et al., 2004a), az Óvodaiskola szervezeti keret (Gáspár, 1990) és a Kudarc nélkül az iskolában komplex prevenciós óvodai program (Porkolábné Balogh et al., 1997). Egy gyakorlat adaptált: a Lépésrőll Lépésre gyermekközpontú program (Klaus, 2004).

\section{A gyakorlatok megalapozottsága}

Három csoport rajzolódott ki: az explicit megalapozottság nélküli; az elméleti megalapozottságú; és a tartalmi szabályozás dokumentumaiba ágyazott gyakorlatok. (1. függelék)

A vizsgált 42 gyakorlatból 24 nem tárgyalja expliciten, hogy milyen elméleti megfontolásokra, elvekre épül. A szerzők csak a saját gyakorlatukat mutatják be, nem reflektálnak másokéra. A napi nevelőmunkában érzékelhető problémákra keresnek megoldásokat, de a problémák természetét nem elemzik, a publikációkban nincs explicit reflexió a céljaikhoz és eszközeikhez kapcsolódóan. 
12 gyakorlat közlői illesztik be azt elméleti keretekbe jó gyakorlatuk bemutatását, ebből négy kutatások eredményein alapul. A kutatói teamek által kidolgozott gyakorlatok, programcsomagok, rendelkeznek pedagógiai koncepcióval (Gáspár, 1990; Porkolábné Balogh et al., 1997; Deliné Fráter, 1997; Nagy et al., 2004a), valamint részletesen kidolgozott tanítási-tanulási programmal; tartalmazzák a tanulási-tanítási egységek leírásait; a tanítási-tanulási eszközöket; illetve az értékelési eszközrendszert (vö. Falus et al., 2012). A kutatói kidolgozású gyakorlatok közül három számol be részletesen a gyakorlat kidolgozási és/vagy továbbfejlesztési folyamatáról (Gáspár, 1990; Porkolábné Balogh et al., 1997; Nagy et al., 2004a). Közülük a DIFER Programcsomag épül alapkutatásra, így ez a legkomplexebb, legkidolgozottabb program.

A DIFER Programcsomag (Nagy et al., 2004a) kötődik a legkorábbi kutatásokhoz, mivel a Preventív fejlettségvizsgáló rendszer (PREFER) fejlesztésének eredményeképp jött létre (Nagy, 1976; 1980) az 1990-es évek elején. A programcsomag számos elemből áll és folyamatosan bővül. Jelen elemzésbe csak a fejlesztéssegítés elméleti kereteit és leírását közlő publikációkat soroltam be, az egyes készségterületek fejlesztőprogramjait nem. A gyakorlati tapasztalatokat összegző tanulmányok közül hivatkozom később néhányra; a bővülő programcsomagról részletesen a saját honlapja tájékoztat (DIFER programcsomag, n.d.).

A DIFER Programcsomag (Nagy et al., 2004a) jól kidolgozott, pszichometriai alapokra épül. A kutatók nagymintás, országos adatfelvételekkel $(\mathrm{N}=10.000+)$ tárták fel a mérőeszköz működését, jóságát, a DIFER-készségek fejlődési folyamatát, a gyermekek közötti fejlettségbeli különbségeket és a fejlesztőprogramok eredményességét. A PREFER teszttel végzett kutatások során a hatéves gyermekek között ötévnyi mentális fejlettségbeli különbséget találtak (például Nagy, 1980). Következtetésként arra hívták fel a figyelmet, hogy az azonos óvodai csoportos fejlesztésből a gyerekek különböző mértékben profitálnak, ezért szükséges a közös fejlesztés kiegészítéseként a lemaradó gyerekek számára külön fejlesztést biztosítani (Nagy, 1974a;1974b). Az első osztályos tanulók 30 százalékánál szükséges az elemi alapkészségek célirányos fejlesztése (Józsa, 2016).

A DIFER Programcsomag (Nagy et al., 2004a) kritikus elemi készségek fejlesztésére helyezi a hangsúlyt. A kritikus elemi készségek közé sorolják a szerzők a következőket: írásmozgás-koordináció; beszédhanghallás; relációszókincs; elemi számolási készség; tapasztalati következtetés; tapasztalatai összefüggésmegértés; szocialitás. Ezek lefedik az elméleti áttekintésben azonosított iskolakezdést meghatározó területeket. Nagy József (2003; 2008) kutatásai alapján a készségfejlesztést addig kell folytatni, amíg az optimális fejlettségi szintet el nem érik a gyerekek. Ha a gyermek még nem érte ezt el az óvodában, akkor a fejlesztés az iskolában is folytatható azonos céllal és módszertannal.

Az Óvodaiskola szervezeti keret (Ovi-Suli) két évet felölelő kísérlet tanulságaira épül. Kidolgozása az 1980-as évekre nyúlik vissza: 1981-ben vette kezdetét az úgynevezett óvoda-iskolai kísérlet egy elsős csoportban Mihály 
Ottó szakmai irányításával Pécsen az Apáczai Csere János Nevelési Központban. A kísérlet első évében a környezet állandóságára fókuszáltak - vagyis a csoportot az óvodában helyezték el. A gyermekekkel egy számukra idegen, ismeretlen óvodapedagógus és tanító foglalkozott. Ezt követően a kísérlet második évében, 1982-ben két elsős csoportot indítottak, melyben már a tárgyi környezet állandóságának megteremtése helyett a pedagógusok személyi állandóságát teremtették meg - vagyis a gyermekekkel együtt ment az iskolába az az óvodapedagógus, aki már a kiscsoporttól kezdve nevelte őket, így a gyerekeket az ismeretlen iskola épületében egy ismert óvodapedagógus és egy idegen tanító fogadta (Gáspár, 1990; Németh, 1993).

Az első két kísérleti év tapasztalataiból levont egyik lényeges tanulság az, hogy az első osztály helyett már nagycsoportban kell elindítani a programot, mivel az 5-8 éves kor egységes szakasz az egyéni fejlődés szempontjából, ugyanakkor az adott szakaszon belül egy-egy gyermek fejlődése között akár 1,5-3 éves fejlettségbeli eltérés is lehet, melyhez az Óvodaiskola szervezeti keret képes igazodni (Németh, 1993). Nagy József kutatási eredményei (1980) ennél nagyobb (akár ötévnyi) fejlettségbeli eltérést azonosítottak a 4-8 éves gyermekek között. A két kísérleti év másik lényeges tanulsága az, hogy az óvodapedagógusok nem érezték magukat kompetensnek a tanítói feladatok ellátására, így a kutatók úgy döntöttek, hogy 1983-tól már a leendő első osztályos tanítók kezdenek el az óvodai nagycsoportban foglalkozni a gyermekekkel (Németh, 1993). A kísérleti szakaszt követően több városban is elterjedt (Borsiné Lódri, 1997, 2001; Kis, 2012; Kovács, 2012; Kristofori, 1994; Márványköviné Jászberényi, 1994, 1995; Szalontai et al., 2012; Reidl, 2012; Zsíros, 2012). Az Óvodaiskola szervezeti keret a képességfejlesztés helyett az intézményváltásra fókuszál, mivel az átmenetet egyrészt az érzelmi biztonság kialakításával segíti - vagyis az óvodában és az iskolában azonos tárgyi, környezeti és személyi feltételek megteremtésére helyezik a hangsúlyt; másrészt azonos módszertant alkalmaznak az átmenet megkönnyítésére (Mihály, 1999).

A Kudarc nélkül az iskolában komplex prevenciós óvodai program (Porkolábné Balogh et al., 1997) kidolgozása szintén az 1980-as években kezdődött. A program fejlődés- és neveléslélektani, neurológiai, illetve gyógypedagógiai megalapozottságú. A kidolgozásának első kísérleti szakasza 1980 és 1984 között valósult meg, amely során keresztmetszeti vizsgálattal négy éven keresztül nyomon követték a nagycsoportos óvodás gyermekek alábbi képességeinek fejlődését: (1) pontos és differenciált vizuális észlelés (például méret, szín pontos felfogása); (2) a hallott információk pontos észlelése és megkülönböztetése; (3) az összerendezett finom- és nagymozgások; (4) a rövidtávú vizuális- és verbális emlékezet; (5), valamint a figyelem fenntartása. Ezenfelül követték az iskolai beilleszkedésüket és a tanulmányi teljesítményüket az általános iskola felső tagozatáig. Külön csoportokat hoztak létre az alsó tagozatot sikeresen teljesítő és a tanulási zavarral küzdő tanulókból. Félévenként összehasonlító elemzéseket végeztek az alsó tagozatot sikeresen 
teljesítő és a tanulási zavarral küzdő tanulók óvodáskori pszichológiai teszteken nyújtott teljesítménye alapján. Ezekkel az elemzésekkel feltárták, hogy a tanulási sikerességet milyen pszichikus funkciók eredményezték, valamint a tanulási problémákat melyik fejlettségbeli lemaradása okozhatta. Az eredményeik alapján fejlesztették ki a programjukat, amely az óvodai nevelés teljes időszakát felöleli (Porkolábné Balogh et al., 1997).

A Lépésrôl Lépésre gyermekközpontú programot eredetileg észak-amerikai neveléstudományi és pszichológus szakemberek, illetve pedagógusok dolgozták ki, majd világszerte számos helyen alkalmazták. A hazai adaptálási folyamat 1996-1998 között zajlott, melyről Deliné Fráter Katalin (1997) számol be: a Hajdúböszörményi Óvóképző Főiskola munkatársainak és a velük közreműködő óvodapedagógusoknak köszönhetően óvodai programot, majd a Budapesti Tanítóképző Főiskola vezető oktatóinak koordinálásával iskolai programot vezettek be. A programot már a 2000-es évek elején több hazai város nevelési-oktatási intézménye alkalmazta (Görcs, 2000; Jékiné Szabó \& Göndöcs, 2002; Földes, 2002).

A Lépésröl Lépésre gyermekközpontú programot Hunyady Györgyné (1998) a reformpedagógiához vezeti vissza. Megjelennek benne a Montessori-pedagógiából ismert elemek (például egyéni fejlesztés célirányosan kiválasztott eszközök segítségével), a Freinet-pedagógia elemei (például kíváncsiságra építő tanítás-tanulás), rogersi elvek (például a gyermek szabad megnyilvánulásaira, gondolataira, érzéseire épülő tanítás-tanulás) és a Waldorf-pedagógia antropozófiai, filozófiai és ismeretelméleti alapjai. A tanulás értelmezésükben és fejlesztési stratégiáikban Jean Piaget munkássága jelenik meg. E szerint a tanulás a tanuló gyermek kíváncsi és aktív lényében, a külvilágban megjelenő problémák és kihívások és a gyerek közötti interakció eredményeként keletkezik, a gyermekeknek a saját erejüket mozgósítva kell új ismereteket szerezniük. Ezek következtében a Lépésröl Lépésre gyermekközpontú program sajátossága az úgynevezett óvodai (például művészeti, építő) és iskolai (például író, olvasó, matematikai) tevékenységi sarkok kialakítása, amelyekben a taneszközök szabadon felhasználhatók. A tananyag müveltségterületi blokkokban történő elrendezése lehetővé teszi a projektoktatás megvalósulását. A gyerekek az új ismeretanyagot csoportokban (4-6 fó) sajátítják el, rugalmas időbeosztás mellett; nagy hangsúlyt fektetnek a gyakorlásra. A program sajátos eleme a faelemekből álló építőkocka-rendszer, amely a matematika és a társadalomismeret tanulásában, illetve a szabadidő hasznos eltöltésében szolgál alapul. Az óvoda-iskola átmenetet azáltal segíti, hogy az óvodai és az iskolai program a személetében, a módszertanában, a képességfejlesztésben és a tárgyi-környezeti feltételeiben azonos pedagógiai modellt képvisel (Hunyadyné, 1998).

Az elméleti megalapozottságú gyakorlatok között nyolc további illeszti a beavatkozást elméleti keretbe, bár nem a szerzők saját kutatásain alapulnak. Novák Gábor (1998) által bemutatott gyakorlat leginkább a fentebb tárgyalt Kudarc nélkül az iskolában komplex prevenciós óvodai programon alapul, 
vagyis ugyanazokra a fejlesztési területekre helyezi a hangsúlyt, mint Porkolábné Balogh Katalin és munkatársai (1997). A hasonlóságok mellett a kettő program eltér a felölelt időszakban, a célcsoportjában, a foglalkozások helyszínében és a képességfejlesztésre használt eszközeiben.

A START könnyítő óvodai program (Pozsonyi \& Tóthné Balogh, 2005a, 2005b) a DIFER Programcsomaghoz hasonlóan nagy hangsúlyt fektet a gyermekek fejlettségi szintjének komplex feltárására és a minél korábbi életszakaszban elkezdődő differenciált, egyéni, játékos kognitív képességfejlesztésre. Egymástól eltérnek a felölelt időszakban, a célcsoportjukban, a foglalkozások helyszínében, a képességfejlesztésre használt eszközeikben és a foglalkozásokat vezető személyek mivoltában.

Kutiné Adorján Györgyi (1990), illetve Szalayné Szöllősi Margit (1997) gyakorlata a gyermekek képességeit feltáró tesztekre, illetve különböző feladatgyüjteményekre támaszkodik. Hamrák Anna (1994) az úgynevezett Lassitott iskolakezdési programot dolgozta ki, mely a reformpedagógia alapjaira vezethető vissza: aktív részvételen, önálló feladatvégzésen, biztonságérzetet nyújtó környezeten és szituációs játékba ágyazott cselekvéses tevékenységeken alapul. Pintér Katalin (2007) az óvoda-iskola átmenet segítésére 1996-ban az Égig érő fa programot közölte, amely szintén reformpedagógiai alapokhoz nyúl vissza: gyermekközpontú, az egyéni fejlesztés elősegítésére helyezi a hangsúlyt, jellemzője a rendszeres gyakorlás és ismétlés, valamint a szabad játék. Körösné Mikis Márta (2006) a játékos informatikai foglalkozások hatékonyságát igazoló kutatásokra támaszkodik. Bondor Mónika (2019) gyakorlata olyan hazai tanulmányokra épít, melyek azt foglalják össze, hogy a különböző fejlesztő játékokkal hogyan tehetők változatosabbá a tanítási órák.

Hat olyan gyakorlatot találtam, amelyek a tartalmi szabályozás dokumentumaiba ágyazottak, vagyis kimondottan az Alapprogram (2012) vagy a NAT (2012) fö irányelveit tekintik kiindulópontnak. Ezek tartalmi szabályozás dokumentumait konkretizálják, lépésekre bontják, ezáltal megvalósíthatóvá teszik az Alapprogram (2012) és a NAT (2012) fö irányelveit.

\section{Megcélzott területek}

A közlemények tartalmát, explicit céljait és tartalmait vizsgálva találtam 31 programot, amely az új intézmény és a tanítók megismertetésére irányul, és 17 programot, amely a képességfejlesztésre irányul. Ezt a két célt 8 gyakorlat ötvözte. (1. függelék)

Az új intézmény és a tanítók megismertetésének hat különböző módja jelenik meg a vizsgált óvoda-iskola átmenetet segítő gyakorlatokban. A legygyakoribb a szülői értekezletek szervezése, melyeken az iskola igazgatója az iskola pedagógiai programját, céljait, házirendjét, követelményeit, elvárásait, valamint a szükséges tanszereket ismerteti; gyakori a tankönyvek bemutatása is. Van, ahol az iskolaigazgató bemutatóját kiegészíti a leendő első osztályos tanítók bemutatása, valamint az iskola gyógypedagógusa, fejlesz- 
tőpedagógusa, pszichológusa által tartott előadás; leginkább az iskolaérettség jellemzőiről, a kisiskolás gyermekek fejlődési sajátosságairól (Bischofné Blandl et al. 2012; Czihlár, 1997; Decsiné Lovasi, 1994; Deliné Fráter, 1997; Esztergomi, 2012; Fazekas, 2015; Gáspár, 1990; Kócza, 1995; Kovácsné Papp, 2010; Kozákné Szentgyörgyi, 2011; Krajcsi, 2000; Lovrity, 1984; Murányiné Sipőcz, 2001; Nagy, 2017; Nagy-Borús, 1998; Novák, 1998; Pintér, 2007; Sóstói, 2002; Szabó \& Gacsályi, 2013; Szabóné Sóvágó, 2011; Szabóné Szél, 2002; Szalayné Szöllősi, 1997; Szalóky, 1994; Vágásiné Vajda, 2012).

Gyakori az iskolai nyílt napok szervezése is. Ezeken a nagycsoportos óvodás gyerekeknek a leendő tanítók bemutatják az iskola helyiségeit, illetve részt vehetnek az elsősök tanítási óráin és a különböző iskolai foglalkozásokon is (Bischofné Blandl et al. 2012; Czihlár, 1997; Deliné Fráter, 1997; Dömény, 2012; Esztergomi, 2012; Fazekas, 2015; Gáspár, 1990; Gráczer, 2013; Kócza, 1995; Kósáné Ormai, 2017; Kozákné Szentgyörgyi, 2011; Krajcsi, 2000; Murányiné Sipőcz, 2001; Nagy, 2017; Szabóné Sóvágó, 2011; Vágásiné Vajda, 2012; Varga, 1996).

Kilenc gyakorlat eleme, hogy a tanító meglátogatja és megfigyeli az óvodai foglalkozásokat, így betekintést nyer az óvodai nevelés és tanulás folyamatába, megismeri a gyerekek közösségben való viselkedését, illetve az óvodapedagógustól információt szerez a gyermekekről (Gráczer, 2013; Krajcsi, 2000; Kutiné Adorján, 1990; Lovrity, 1984; Murányiné Sipőcz, 2001; Pányiné Segesdi, 2004; Szabóné Sóvágó, 2011; Tóth \& Soósné Hűse, 2013; Varga, 1996).

Hat gyakorlatnál jelenik meg a közös óvodai és iskolai ünnepségek, programok (például Mikulás-napi ünnepség) szervezése, amelyek lehetőséget adnak arra, hogy a leendő elsős gyerekek megismerjék az iskola épületét, a leendő tanítót és a többi iskolás gyermeket (Bischofné Blandl et al. 2012; Fazekas, 2015; Kósáné Ormai, 2017; Kozákné Szentgyörgyi, 2011; Pálfi, 2019; Pányiné Segesdi, 2004).

Három gyakorlat tartalmaz családlátogatást az iskolakezdést megelőző nyári hónapokban (Decsiné Lovasi, 1994; Esztergomi, 2012; Tóth \& Soósné Hüse, 2013). Csupán két gyakorlatnál jelenik meg, hogy az óvodapedagógusok az iskolakezdést követő néhány hónapban meglátogatják a gyerekeket az iskolában (Kócza, 1995; Sóstói, 2002).

Abban a 18 gyakorlatban, amelyek a képességfejlesztést helyezték a középpontba, a kognitív fejlesztést találtam a leggyakoribbnak, kevésbé jelent meg a szociális és érzelmi, illetve a motoros terület. A kognitív területen belül leginkább a figyelem és a szókincs fejlesztését célozzák a szerzők; kisebb arányban jellemzőek a gondolkodási műveletek; legkevésbé jellemző a számolás fejlesztése. A szociális és érzelmi területen belül a legjellemzőbb a kapcsolatfelvétel és a feladattartás fejlesztése; megjelenik még a feladatvállalás és az erkölcsi érzék fejlesztése is. A motoros területen belül az írásmozgás-koordináció, illetve a ritmusérzék kap figyelmet (Alföldiné Hende et al. 2013; Bondor, 2019; Deliné Fráter, 1997; Gáspár, 1990; Hamrák, 1994; Kovács \& Kakuk, 2013; Kovácsné Papp, 2010; Kőrösné Mikis, 2006; Kutiné Adorján, 1990; Lovrity, 1984; Nagy 
et al. 2004a; Novák, 1998; Pap, 2016; Porkolábné Balogh et al. 1997; Pozsonyi \& Tóthné Balogh, 2005a; Szalayné Szöllősi, 1997; Szigetiné Sulyok, 2012).

Összességében elmondható, kevésbé jellemző a fejlesztési folyamat részletezése; gyakoribb az általános megfogalmazás, a fejlesztendő területek felsorolása, illetve néhány feladat, játékötlet kiemelése. Ez alól kivétel a DIFER Programcsomag (DIFER programcsomag, n.d.).

\section{A gyakorlatok müködtetésének feltételei}

Az egyes gyakorlatok feltételeit részletesen a 2. függelék mutatja be. Az áttekintett gyakorlatok többségének (31) müködése személyi feltételekhez kötődik. Ebből 26 kívánja meg expliciten a pedagógusok és a szülők közötti együttműködést; 21 az óvodapedagógusok és tanítók közötti együttműködést feltételezi. Csak négy kötődik továbbképzésen való részvételhez, tehát a legtöbb gyakorlat a megvalósításhoz nem kíván speciális felkészültséget. Elenyésző az olyan programok száma, amelyek kéttanítós modellt javasolnak (két tanító foglalkozik a gyerekekkel) vagy kétdiplomás pedagógust (a gyerekkel foglalkozó személy óvodapedagógiai és tanítói végzettséggel is rendelkezik).

22 gyakorlat speciális eszközökhöz és/vagy sajátos térrendezéshez kötődik. Az előbbi a gyakoribb: gyakorlatonként változóan szőnyeg, a gyerekek munkáit tartalmazó dossziék, a képességfejlesztéshez kapcsolódó eszközök, babzsák, bábok szükségesek hozzájuk. A sajátos térrendezés esetén az elsődleges szempont, hogy az iskola környezeti-tárgyi feltételei azonosak legyenek az óvodáéval, vagyis a teremben a gyerekek méreteihez illeszkedő, könnyedén mozgatható padok és asztalok legyenek. Számos gyakorlat sajátossága az iskolai tanteremben berendezett játszósarok.

Összességében látható, hogy a hazai publikált óvoda-iskola átmenetet segítő gyakorlatok Britto által azonosított három dimenzió közül (2012, p. 6-8) leginkább a gyerekek átmenetben való megsegítésére fókuszálnak. A gyakorlatok fele foglalkozik a család megsegítésével az érintett átmenet során. Ezek megkívánják a szülők és a pedagógusok közötti együttműködést. Ugyanakkor a szülők bevonására csak a szülői értekezletek adnak lehetőséget. Az elemzésem rávilágított arra, hogy az iskolák fele az óvodához hasonló környezeti-tárgyi feltételek megteremtésével próbál felkészülni az átmenet megsegítésére.

\section{A gyakorlatok által felölelt idöszak}

A 2. ábrán látható, hogy a feltárt gyakorlatok milyen időintervallumot fednek le az átmenetből. A vízszintes tengelyen az óvodai nagycsoport utolsó éve és az általános iskola első évfolyama található. A leghosszabb időszakot felölelő gyakorlat a vízszintes tengelyhez legközelebb helyezkedik el. A vonalak vastagsága illusztrálja a gyakoriságot, vagyis minél vastagabb egy vonal, annál több gyakorlat vonatkozik az adott időintervallumra. Három publikáció ja- 
vasol az óvoda utolsó éve és az általános iskola első évfolyama közé illesztett iskola-előkészítő osztályt. Ezeket a 2. ábrán nem szerepeltetem.

2. ábra

A gyakorlatok által lefedett időszak

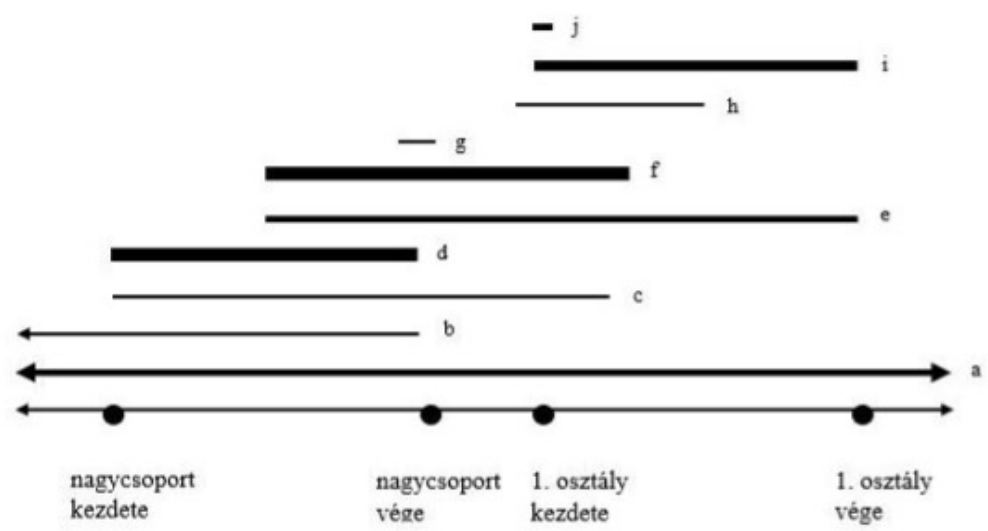

Megjegyzés: a lefedett intervallum szerinti gyakorlatcsoportok:

a: Gáspár (1990); Deliné Fráter (1997); Nagy et al. (2004a)

b: Porkolábné Balogh et al. (1997)

c: Esztergomi (2012); Kócza (1995)

d: Czihlár (1999); Kósáné Ormai (2017); Kutiné Adorján (1990); Krajcsi (2000);

Lovrity (1984); Murányiné Sipőcz (2001); Szabóné Szél (2002); Szabóné Sóvágó

(2011); Tóth E Soósné Hüse (2013); Varga (2016)

e: Decsiné Lovasi (1994); Dömény (2012); Nagy (2017);

f: Alföldiné Hende et al. (2012); Bischofné Blandl et al. (2012); Fazekas (2015);

Kovácsné Papp (2010); Kozákné Szentgyörgyi (2010); Pányiné Segesdi (2004); Pap (2016); Pozsonyi \& Tóth Balogh (2005a); Szabó E Gacsályi (2013); Vágásiné Vajda (2012)

g: Gráczer (2013)

h: Körösné Mikis (2006); Sóstói (2002)

i: Bondor (2019); Hamrák (1994); Pálfi (2019); Pintér (2007)

j: Nagy-Borús (1997); Szalóky (1994); Szigetiné Sulyok (2012)

A leghosszabb időintervallumot lefedő gyakorlatokat kutatók, elméleti szakemberek dolgozták ki. A gyakorló pedagógusok által közöltek legfeljebb egy tanévet ölelnek fel. A leggyakoribb az óvodai nagycsoport teljes időszakát, illetve az óvodai nagycsoport második félévétől az általános iskola első néhány hónapját felölelő gyakorlat. Az utóbbiak többségét tanítók dolgozták ki. Ezek az intézményváltásra fókuszálnak.

Három olyan gyakorlatot találtam, amely az óvoda utolsó éve és az általános iskola első évfolyama közé illesztett (Szalayné Szöllősi, 1997; Novák, 
1998; Kovács \& Kakuk, 2013). Ezeket nem helyeztem el a 2. ábrán. E gyakorlatok intenzív iskola-előkészítő osztályként müködnek, az iskolára még nem megfelelő mértékben érett gyerekekkel, a gyerekeket az óvodából kiemelve foglalkoznak. A feltárt három gyakorlat kevésbé kidolgozott, az átmenetben a környezet, a tevékenységek és a pedagógusok állandóságára helyezik a hangsúlyt, a képességfejlesztés kevésbé tünik hangsúlyosnak. A szerzők a bevezetésüket nem támasztják alá elméleti alappal, illetve nem közölnek adatokat a hatásvizsgálatukról sem.

Az iskola-előkészítő osztályok szervezése nem új keletű, az 1970-es évekig nyúlik vissza. A hazai szakirodalomban az iskola-előkészítő osztály mellett jellemző a felzárkóztató, a felkészítő, illetve a fejlesztő osztály kifejezés használata is. Ezek bevezetése és hatékonysága vitatott, azonban a tanulmányomnak nem feladata részletes állást foglalni ebben a kérdésben.

Nagy József (2012) azt állítja, hogy már hosszú évtizedek óta bizonyított, hogy a tanulók fejlettség szerinti homogén csoportokba rendezése következtében a szociális és értelmi fejlődésük tovább romlik. Különböző kutatások eredményei (például Józsa, 2007) arra hívták fel a figyelmet, hogy az óvodásés kisiskoláskorban a gyermekek készségfejlődése kritériumorientált módszerekkel (például Csordásné Anda \& Józsa, 2007) nagymértékben segíthető. A sikeres iskolakezdés feltételei megteremthetőek, az egyéni hátrány mértéke csökkenthető elkülönítés nélkül is (például Józsa \& Zentai, 2007b).

Ezek ellenére a 2018-as NAT tervezet (Nemzeti Alaptanterv, 2018) felvetette az úgynevezett felkészítő évfolyam bevezetését, mely fő célja a mozgás fejlesztése (például egyensúlygyakorlat, ritmusérzék és izomtónus-fejlesztő gyakorlatok), a kommunikációs képesség fejlesztése, az érzékelés, az észlelés, a figyelem, az emlékezet és a logikai készségek fejlesztése.

Többen (például Villányi, 2018) felvetettek a felkészítő évfolyamhoz kapcsolódó személyi, tárgyi és módszertani kérdéseket. Személyi kérdéseik közé tartozik például az, hogy a tanítók ismerik-e az óvodai módszereket; a tanítói diploma elegendő-e az iskolára éretlen óvodáskorú gyermekek fejlesztéséhez. Tárgyi feltételekhez kötődő kérdéseik javarészt arra vonatkoztak, hogy az osztályteremben, padsorokban ülve történne a fejlesztés vagy gyermekközpontú, a gyermekek számára már ismert óvodai környezetben; hogyan oldaná meg az iskola a pihenést, az alvást a gyerekek számára. A módszertanra vonatkozó kérdéseik arra irányultak, hogy tanórákat vagy fejlesztő foglalkozásokat tartanának; naponta mennyi tanóra vagy fejlesztő foglalkozás lenne (Villányi, 2018). Empirikus kutatásokkal még nem alátámasztott, de a gyakorló pedagógusok állásfoglalásai szerint az iskolai-felkészítő évfolyamok szegregációhoz vezetnek, megbélyegzik a gyerekeket és a személyiségfejlődésükben maradandó károsodást okozhatnak (Bartáné Tóth, 2018). 


\section{A gyakorlatok hatásvizsgálata}

A feltárt 42 gyakorlat közül csak öt kidolgozói közölnek hatásvizsgálatot. Ezeket egy kivételével a kutatók dolgozták ki.

A DIFER készségfejlesztő programjainak hatékonyságát fejlesztőkísérletek keretében vizsgálják a kidolgozók. A programcsomagot elsősorban nem a hátrányos helyzetű gyermekek fejlesztése céljából dolgozták ki, de a különböző longitudinális vizsgálatok (például Józsa \& Zentai, 2007a, 2007b) igazolták, hogy az ő alapkészségeik is hatékonyan fejleszthetők vele.

A mesékhez kapcsoló tematikus beszélgetések hatékonyságát Nyitrai Ágnes \& Zentai Gabriella (2012) 2007 és 2009 között elvégzett fejlesztő kísérlete támasztotta alá. A kétéves kísérlet végén szignifikánsan jobban teljesítettek az összefüggések megismerésének, megértésének és alkalmazásának készségeit feltáró teszten a kísérleti csoport tagjai, mint a kontrollcsoport (Cohen-féle $\mathrm{d}=0,84$ ).

Több fejlesztőkísérlet igazolta, hogy a „beszédhangok tulajdonságaik szerinti differenciálása, valamint a beszédhangok sorozatának felfogása" (Fazekasné Fenyvesi \& Józsa, 2012, p. 1-2) eredményesen fejleszthető. Ilyen például Fazekasné Fenyvesi Margit \& Józsa Krisztián (2011) 2009/2010-es nevelési évben megvalósuló fejlesztő kísérlete, amelyben középső, majd nagycsoportos óvodások vettek részt. A kísérleti csoportban 100, a kontrollcsoportban 82 gyermek volt. A középső csoportos óvodások tíz hónapos fejlesztésének következtében a kísérleti csoportban lévő gyerekek beszédhanghallásának fejlettségi szintje szignifikánsan felülmúlta a kontrollcsoportba tartozó óvodásokét (Cohen-féle $\mathrm{d}=0,62$ ).

A DIFER Programcsomag bővítése során a hatásvizsgálat feltárása továbbra is alapelvként jelenik meg. Például a sorrend megállapításának és a viszonyok felismerésének képessége (például Zentai \& Józsa, 2014), illetve a zenei képességek (például Janurik \& Józsa, 2016) is hatékonyan fejleszthetők. A fejlesztőkísérletekben kipróbált módszerek játékgyűjitemény formájában jelentek meg (például Fazekasné Fenyvesi, 2006; Józsa, Zentai \& Hajduné Holló, 2017; Miskolcziné Radics \& Nagy, 2006; Nagy, 2009; Nyitrai, 2009, 2016; Nyitrai \& Darvay, 2013; Zsolnai, 2006).

A START könnyítő óvodai program hatékonyságát és eredményességét Pozsonyi Márta és Tóthné Balogh Ágnes (2005a, 2005b) az intelligenciakvóciens, a percepciós kvóciens, a rajzkvóciens, a Diszlexia Prevenciós Szürőteszt eredménye és a passzív szókincs fejlettségi szintjét mérő P.P.V.T. teszteredmények tanév eleji és tanév végi összehasonlításával elemezte a 2002/2003-as tanévben 15 óvodás gyermek bevonásával. A fejlesztés végén nagy fejlődést találtak minden mért területen a gyengébben és a jobban teljesítő tanulók esetében is (Pozsonyi \& Tóthné Balogh, 2005a; 2005b).

A Kudarc nélkül az iskolában komplex prevenciós óvodai program (Porkolábné Balogh et al., 1997) alkalmazhatóságát és hatékonyságát három tanévet (1985-1988) felölelő longitudinális vizsgálattal tárták fel. Két kísérleti 
csoportot indítottak: az egyiket 22, a másikat 27 óvodás gyermek alkotta. Kísérletük a testnevelés és a környezetismeret óvodai foglalkozásokon valósult meg. Az eredményeik alapján a kísérleti csoportban résztvevő gyermekek nagyobb mértékü, intenzívebb fejlődést értek el az összes mért területen, mint a kontrollcsoport tagjai. A két csoport közötti legnagyobb eltérés a testséma kialakulásában és a mozgásfejlettségben mutatkozott meg.

Az Óvodaiskola szervezeti keret hatását Sz. Németh Ildikó (1993) és T. Pusztafalvi Henriette (1993) érintett felnőttek kikérdezésével vizsgálta. Sz. Németh (1993) két intézményvezetővel és hat tanítóval, illetve T. Pusztafalvi Henriette (1993) 20 első osztályos gyermeket nevelő szülővel készített interjút. Mindkét vizsgálatban úgy nyilatkoztak az interjúalanyok, hogy hatékonynak tartják az Ôvodaiskola szervezeti keretet, mivel megoldja az óvoda-iskola átmenet legfőbb problémáját: a környezet megváltozását.

A Lépésről Lépésre gyermekközpontú program hatásvizsgálatáról számol be Gyarmati Attiláné (2000) és Földes Petra (2002) tanulmánya. Gyarmati Attiláné (2000) az 1996/97-es tanév tapasztalatai alapján kiemeli, hogy az első osztály végén a kísérleti osztály tanulói matematikából és magyarból jobb teljesítményt értek el, mint a kontrollcsoport tanulói. Nem közöl azonban adatokat a kísérleti- és a kontrollcsoportról, illetve statisztikai próbákról sem. Ezenfelül Gyarmati Attiláné (2000) kiemeli, hogy a kísérletben résztvevő osztályt tanító két pedagógus pozitív változást tapasztalt a gyermekek neveltségi szintjének alakulásában. Földes Petra (2002) interjút közölt egy iskolaigazgatóval, aki arról számolt be, hogy a Lépésröl Lépésre gyermekközpontú programban tanuló második osztályos hátrányos helyzetü gyerekek ugyanolyan eredményt értek el, mint az átlagos helyzetű kontroll osztály, ugyanakkor ő sem közölt számadatokat, statisztikai próbát.

Összességében látható, hogy a publikált gyakorlatok többségénél nincs információnk a gyakorlat hatékonyságáról, így nem ismert, hogy a publikált gyakorlatok mennyire járulnak hozzá az átmenet megkönnyítéséhez. Az az öt gyakorlat, melyhez kapcsolódik hatásvizsgálat, igazoltan hozzájárul az óvoda-iskola átmenet megkönnyítéséhez, az iskolai tanulás hatékonyságához, azonban ezt csak a DIFER Programcsomag esetében lehet számszerüen igazolni.

\section{Összegzés}

Az óvoda-iskola átmenet segítése támogató beavatkozás, kérdés azonban, hogy a támogatáshoz programot kidolgozók az átmenetet hogyan - tágan vagy szűken - értelmezik, vagyis a fejlődés és az intézményváltás folyamatait mennyiben veszik célba. Tudományos adatbázisokban 42 ilyen publikált hazai gyakorlatot azonosítottam.

A gyakorlatok többségét gyakorló pedagógusok, leginkább tanítók közölték. Kevésbé jellemző, hogy az óvodapedagógusok és a tanítók együttesen dolgozzanak ki gyakorlatokat. A gyakorlatok szerzőinek többsége az óvoda- 
iskola átmenet során felmerülő nehézségeket a környezet és a személyek megváltozásában látja. Kevesebb gyakorlat célozza a képességfejlesztést. A fejlesztést célzó gyakorlatok többsége a kognitív képességekre helyezi a hangsúlyt, a szociális és érzelmi, illetve a motoros készségek fejlesztése kevésbé jelenik meg, a feltárt gyakorlatok az iskolaérettséggel és az egyéni fejlesztéssel kevésbé foglalkoznak.

Britto (2012) elméleti áttekintésben bemutatott gondolataiból nem lett explicit elemzési szempont, de beágyazva megjelenik két elemzési szempontban is: a megcélzott területek, valamint a gyakorlatok müködtetésének feltételei szempontban. Az elemzés során kiderült, hogy a publikált hazai gyakorlatok főleg a gyerekekre irányulnak. A gyakorlatok felénél jellemző, hogy a családot segítik az átmenetben, azonban ez csak szülői értekezletek szervezésével valósul meg. Az iskolák fele az óvodához hasonló környezet megteremtésével készül fel az iskolakezdésre.

Az óvoda-iskola átmenet megsegítésére felkínált megoldási javaslatok ritkán ágyazottak pszichológiai-pedagógiai elméletekbe, kutatással igazolt elvekbe. A működési feltételek esetén a személyi feltételek hangsúlyosabbak, mint a környezeti-tárgyi feltételek. A személyi feltételek az óvodapedagógusok és a tanítók együttműködését, illetve a pedagógusok és a szülők együttmüködését feltételezik. Elenyésző azoknak a gyakorlatoknak a száma, amelyek továbbképzéshez kötődnek. A fellelt gyakorlatok az átmenet különböző hosszúságú szakaszait fedik le, leggyakoribb az óvodai nagycsoport teljes tanévére kiterjedő program, amelyek többségét tanítók dolgozták ki.

Az átmenet megkönnyítésére kidolgozott gyakorlatok túlnyomó többségénél nem történt hatásvizsgálat, ez leginkább a kutatók, elméleti szakemberek által közöltek esetén feltárt. Közülük a DIFER Programcsomag hatásvizsgálatának a bemutatása a legrészletesebb, mely eredményes a hátrányos helyzetü gyermekek körében is.

Bár számos intézmény pedagógusai tesznek aktívan az átmenet könnyebbé tételéért (például Kálmán, 2016; Nagy, 2018; Gyurcsik, 2020; Markovics, 2020), nem látható, hogy milyen gyakorlatok milyen okból, céllal születnek és valójában mennyire elterjedtek, milyen az erőforrásigényük, illetve az eredményességük, hatékonyságuk megítélése, értékelése. A hazai publikált óvoda-iskola átmenetet segítő gyakorlatok szisztematikus áttekintése, a tanulmányban bemutatott elemzés, segítséget ad az egyes megoldások pedagógiai, kutatói reflexiójához.

\section{Irodalom}

13/2018 (VI. 14.) EMMI rendelete a 2018/2019. tanév rendjéről. Magyar Közlöny. 85. sz.

1993. évi LXXIX. törvény a közoktatásról. http://www.okm.gov.hu/letolt/kozokt/ kozokt_tv_070823.pdf 
2011. évi CXC. törvény a nemzeti köznevelésről. https://net.jogtar.hu/ getpdf?docid $=$ a1 100190.tv\&targetdate $=\&$ printTitle $=2011 .+\%$ C3\%A9vi + CXC. $+\mathrm{t}$ \%C3\%B6rv\%C3\%A9ny

Alföldiné Hende, M., Kasza, J., Ménkű, J., Molnárné Hegedűs, K., Szabóné Nagy, O., Szeremete, G. \& Szilvási, M. (2013). Fogom a kezed. Iskolatáska. Educatio. https://iskolataska.educatio.hu/index.php/jogyakorlatotlet/jogyak_print_show/ jogyakId/1028/1580973443.edu

Apró, M. (2013). A hazai iskolaérettségi vizsgálatok gyakorlata napjainkban. Iskolakultúra, 23(1), 52-71.

Bartáné Tóth, M. M. (2018). Problémafelvetés: óvoda-iskola átmenet. Módszertani Közlemények, 58(3), 3-6.

Bischofné Blandl, M., Fáth, E., Győriné Meiszter, K., Hidasiné Volk, A., Rainer, P. \& Nichterné Ruppert, K. (2012). Sikeres oktatási és nevelési utak. Ajánlások az átmenetek szervezéséhez. Magyarországi Németek Országos Önkormányzata.

Bondor, M. (2019). Az óvoda-iskola átmenet megkönnyítése a LÜK játékkal. Módszertani Közlemények, 58(3), 15-22.

Borsiné Lódri, E. (1997). Az óvodaiskola. In Benedek, I. (Ed.), Óvodavezetés másképpen?! (pp. 166-189). Okker Oktatási Iroda.

Borsiné Lódri, E. (2001). Innovációs törekvések a Károlyi Mihály utcai Óvodában és Óvodaiskolában. Módszertani Közlemények, 41(2), 72-74.

Britto, P. R. (2012). School readiness: A conceptual framework. United Nations Children's Fund. https://www.unicef.org/earlychildhood/files/Child2Child_ ConceptualFramework_FINAL(1).pdf

Commodari, E. (2013). Preschool teacher attachment, school readiness and risk of learning difficulties. Early Childhood Research Quarterly, 28(1), 123-133.

Czihlár, K. (1997). Hogyan várjuk őket? Módszerek és tapasztalatok az első osztályosok fogadására. Tanitó, 35(7), 15.

Csordásné A, É. \& Józsa, K. (2007). A számolási készségfejlesztése hátrányos helyzetü elsö osztályos tanulók körében. VII. Országos Neveléstudományi Konferencia, 41.

Decsiné Lovasi, M. (1994). Elsős lesz a gyermekem! Kulcslyuk Kiadó.

Deliné Fráter, K. (1997). Lépésről lépésre: óvodafejlesztő program. Deli Kiadó.

DIFER programcsomag (n.d.). http://www.edu.u-szeged.hu/difer/?pid=bemutatas (2020.07.21.)

Dockett, S. \& Perry, B. (2002). Who's ready for what? Young children starting school. Contemporary Issues in Early Childhood, 3(1), 67-89.

Dömény, I. (2012). A korai fejlesztés és a sikeres óvoda-iskola átmenet gyakorlati megvalósulása egybajaióvodában. In Tóth, S. A.(Ed.), Hatékonyság, eredményesség és multidiszciplinaritás. Segédanyagok pedagógusképzésben résztvevők számára. (pp. 45-53). Eötvös József Főiskolai Kiadó. 
Duncan, G. J., Dowsett, C. J., Claessens, A., Magnuson, K., Huston, A. C., Klebanov, P., Pagani, L., Feinstein, L., Engel, M., Brooks-Gunn, J., Duckworth, K., Japel, Ch. \& Sexton, H. (2007). School readiness and later achievement. Developmental Psychology, 43(6), 1428.

Esztergomi, K. (2012). Iskolába hívogató a Palánta Általános Iskolában. In Kereszty, Zs. (Ed.), Gyermekközpontú módszerek. Módszertani válogatás alternatív iskolák jó gyakorlataiból. (pp. 34-46). Educatio Társadalmi Szolgáltató Nonprofit Kft.

Fabian, H. (2007). Informing Transitions. In Dunlop, A. and Fabian, H. (Eds.), Informing transitions in the early years (pp. 3-17). Open University Press.

Falus, I., Környei, L., Németh, Sz. \& Sallai, É. (2012). A pedagógiai rendszer. Fejlesztők és felhasználók kézikönyve. Educatio Társadalmi Szolgáltató Nonprofit Kft.

Fazekas, Sz. T. (2015). Óvoda-iskola átmenet. Iskolatáska. Educatio: https:// iskolataska.educatio.hu/index.php/jogyakorlatotlet/jogyak_print_show/ jogyakId/946/1580907501.edu (2020.02.06.)

Fazekasné Fenyvesi, M. (2006). A beszédhanghallás fejlesztése 4-8 éves életkorban. Mozaik Kiadó.

Fazekasné Fenyvesi, M. \& Józsa, K. (2011). A beszédhiba korrekciója a beszédhanghalló készség fejlesztése alapján: egy kísérlet tapasztalatai. XI. Országos Neveléstudományi Konferencia.

Fazekasné Fenyvesi, M. \& Józsa, K. (2012). A beszédhanghallás és a beszédhiba összefüggése tanulásban akadályozott gyermekek esetében. Gyógypedagógiai Szemle, 40(1), 1-13.

Fisher, J. (2011). Building on the Early Years Foundation Stage: Developing good practice for transition into Key Stage 1. Early Years,31(1), 31-42. http://dx.doi. org/10.1080/09575146.2010.512557

Földes, P. (2002). Lépésről lépésre egy iskolaprogramért. Új Pedagógiai Szemle, 52(5), 138-150.

Gáspár, L. (1990). Óvodaiskola a pécsi Apáczai Csere János Nevelési Központban. Óvodai Nevelés, 43(1), 3-5.

Gerebenné Várbíró, K. \& Vidákovich, T. (1997). A differenciát beiskolázás néhány méröeszköze: a Bender A-, a Budapesti Binet-, a Frostig-, a Goodenough-, a SONés a PREFER-tesztek összehasonlitó vizsgálata. Akadémiai Kiadó.

Golyán, Sz. (2013). Válogatás az óvoda-iskola átmenet európai tapasztalataiból. Gyermeknevelés Tudományos Folyóirat, 1(1), 106-128.

Görcs, I. (2002). Lépésről lépésre. Óvodai nevelés, 5(7), 279-282.

Gráczer, É. (2013). Ovi-suli. Iskolatáska. Educatio. https://iskolataska.educatio.hu/ index.php/jogyakorlatotlet/jogyak_print_show/jogyakId/814/1580971687.edu

Gyarmati, A. (2000). A „Lépésről lépésre” Iskolai Program bevezetése intézményünkben. Új Katedra, (1), 21-23. 
Gyurcsik, A. (2020). Az óvoda-iskola átmenet óvodapedagógusok és tanítók szemével. XVIII. Pedagógiai Értékelési Konferencia.

Gyurcsik, A., Fehér, O. \& Földi, F. (2017). Az iskolaérettség mérésének összehasonlítása Magyarországon és Szerbiában. Gyermeknevelés Tudományos Folyóirat, 5(3), 93-100.

Hair, E., Halle, T. \& Humen, E. T. (2006). Children's school readiness in the ECLS- K: Predictions to academic, Health, and social outcomes in the first grade. Early Childhood Research Quarterly, 21(4), 431-454.

Hamrák, A. (1994). Lassított iskolakezdési program. Iskolakultúra, 4(19), 16-23.

Heckman, J., Grunewald, R., \& Reynolds, A. (2006). The dollars and cents of investing early: Cost-benefit analysis in early care and education. Zero to Three, 26(6), 10-17.

Hunyady, Gy. (1998). Lépésröl lépésre - iskolai program I., II. Budapest: Országos Pedagógiai Könyvtár és Múzeum.

Janurik, M. \& Józsa, K. (2016). A zenei képességek összefüggése a DIFER készségekkel óvodáskorban. Neveléstudomány: Oktatás - Kutatás - Innováció, 4(1), 49-69.

Jékiné Szabó, R. \& Göndöcs, G. (2002). Lépésről Lépésre Program a Pécsi Csokonaiban. Tanitó, 40(4), 17-18.

Józsa, K. (2004). Az első osztályos tanulók elemi alapkészségeinek fejlettsége - Egy longitudinális kutatás első mérési pontja. Iskolakultúra, 14(11), 3-16.

Józsa, K. (2007). Az elemi alapkészségek szerepe az olvasási képesség fejlődésében: egy longitudinális vizsgálat tapasztalatai. Szimpózium előadás. In Korom, E. (Ed.), PÉK 2007 - V. Pedagógiai Értékelési Konferencia: Program - Tartalmi összefoglalók (pp. 55).

Józsa, K. (2014). A számolás fejlesztése 4-8 éves életkorban. Mozaik Kiadó.

Józsa, K, (2016). Kihívások és lehetőségek az óvodai fejlesztésben. Iskolakultúra, 26(4), 59-74.

Józsa, K. (2007). Hátrányos helyzetű gyermekek fejlesztése. In Korom, E. (Ed.), PÉK 2007 - V. Pedagógiai Értékelési Konferencia: Program - Tartalmi összefoglalók (pp. 119-124). SZTE Neveléstudományi Doktori Iskola.

Józsa, K. \& Zentai, G. (2007a). Hátrányos helyzetű óvodások játékos fejlesztése a DIFER Programcsomag alapján. Új Pedagógiai Szemle, 57(5), 3-17.

Józsa, K. \& Zentai, G. (2007b). Óvodások kritériumorientált fejlesztése DIFER Programcsomaggal. In Nagy, J. (Ed.), Kompetencia alapú kritériumorientált pedagógia (pp. 299-311). Mozaik Kiadó.

Józsa, K., Zentai, G. \& Hajduné Holló, K. (2017). A gondolkodás fejlesztése 4-8 éves életkorban. Mozaik Kiadó.

Józsa, K., Csima M., Nyitrai, Á. \& Podráczky, J. (2019). A korai fejlettségi mutatók szerepe az iskolai sikerességben: egy longitudinális kutatás első lépései. In Juhász, E. \& Endrődy, O. (Eds.), Oktatás - Gazdaság - Társadalom. HERA Évkönyvek (pp. 848-860). Magyar Nevelés- és Oktatáskutatók Egyesülete. 
Kagan, S. L., Moore, E., \& Bredekamp, S. (1995). Reconsidering children's early learning and development: Toward shared beliefs and vocabulary. Report of the National Education Goals Panel. Government Printing Office.

Kálmán, L. (2016). Óvodapedagógusok, tanítók és szülők nézetei a gyermekek iskolaérettségéről. MA szakdolgozat. Szegedi Tudományegyetem.

Kende,A.(2008). A rugalmas beiskolázás szerepe az oktatásiszakadék elmélyülésében. Pszichológiai és szociológiai érvek egy oktatáspolitikai intézkedés kapcsán. In Erőss, G. \& Kende, A. (Eds.), Túl a szegregáción - kategóriák burjánzása a magyar közoktatásban (pp. 105-136). L'Harmattan Kiadó.

Kende, A. \& Illés, A. (2007). A rugalmas beiskolázás és az oktatási szakadék összefüggései. Új Pedagógiai Szemle, (11), 17-41.

Kerekes, G., Simon, I. \& Szép, L. (2011). Nemzetközi és hazai bevált gyakorlatok a minőségfejlesztésben. Oktatáskutató és Fejlesztő Intézet.

Kerettanterv az általános iskola 1-4. évfolyama számára. (n.d.). https://www. oktatas.hu/kozneveles/kerettantervek/2020_nat/kerettanterv_alt_isk_1_4_evf (2020.08.27.)

Kis, I. (2012). Óvodaiskola "Vásárhelyi-módra" 5. Tanító Módszertani Folyóirat, 50(1), 19-21.

Kiss, T. \& Szabóné Kálmán, Á. (2002). Az óvoda-iskola átmenet problémáinak kérdése Miskolc városában. Óvodai Élet, 10(3), 36-40.

Kissné Takács, E. (1996). Feladatgyüjtemény a képességszintek megállapitásához. Hajdú-Bihar Megyei Pedagógiai Intézet.

Kissné Takács, E. (2004). Belső Gondozói Rendszer. Óvodai Nevelés, 57(6), 184-190.

Klaus, S. (2004). Stepping into the future: A history of the Step by Step program. Educating Children for Democracy, 8, 3-13.

Kócza, T. (1995). Iskolánk együttmüködése az óvodákkal. Tanitó Módszertani Folyóirat, 33(2), 10-11.

Kolátné Kovács, V. Cs. \& Kormosné Kovács, T. (2015). Gondolatok az óvoda és az iskola közötti átmenetről. Pedagógiai és Módszertani Tanácsadó, 11(4), 57-60.

Kósáné Ormai, V. (2017). Az „akadálymentesített” óvoda-iskola átmenet jellemzői. Tanító, 55(7), 7-11.

Kovács, M. \& Kakuk, Zs. (2013). Óvoda az iskolában. Óvodai Nevelés, 66(10), 25.

Kovács, R. (2012). Óvodaiskola "Vásárhelyi-módra” 3. Tanító Módszertani Folyóirat, 50(3), 10-12.

Kovácsné Papp, Á. (2010). Játékos ismerkedés az iskolával. Tanító Módszertani Folyóirat, 48(9), 29-31.

Kozákné Szentgyörgyi, I. (2011). Lehet-e törésnek nélkül kisiskolás az óvodásból? Tanitó Módszertani Folyóirat, 49(7), 6-9.

Kőrösné Mikis, M. (2006). Ikt az oktatás kezdő szakaszában. Tanító szakmódszertani folyóirat,44(5), 8-9. 
Krajcsi, J. (2000). Egy elsős tanító évindító tapasztalataiból. Tanitó: Módszertani Folyóirat, 38(6), 26.

Kristofori, A. (1994). Óvodaiskola Kecskeméten. Prevenciós, komplex fejlesztés. Óvodai Nevelés, 47(10), 340-341.

Kutiné Adorján, Gy. (1990). Az óvoda-iskola átmenet gondjainak enyhitése egy, a gyermekek megismerésére irányuló eljárással. Tolna Megyei Pedagógiai Intézet.

Ligeti, Cs. (2000). Amikor iskolás lesz a gyermek. Óvodai Élet, 8(2), 30-32.

Lovrity, S. (1984). Az óvoda és az általános iskola együttmüködése. Módszertani Közlemények, 24(5), 261-268.

Markovics, O. (2020). Óvoda-iskola átmenet nehézségei a pedagógusok szemszögéből. MA szakdolgozat. Szegedi Tudományegyetem.

Márványköviné Jászberényi, Á. (1994). Óvodaiskola Kecskeméten. Óvodai Nevelés, 47(9), 306-308.

Márványköviné Jászberényi, Á. (1995a). Óvodaiskola Kecskeméten. Csengőszó, 3(2), 28-32.

Mérei Ferenc, \& V. Binét, Á. (1978). Gyermeklélektan. Gondolat Kiadó.

Mihály, O. (1999). Gyakorlati válaszok: fejlesztések, kísérletek Szolnoktól Pécsig. In Horváth, A. \& Trencsényi, L. (Eds.), Az emberi minőség esélyei. Pedagógiai tanulmányok. (pp.205-225). Okker Kiadó.

Miskolcziné Radics, K. \& Nagy, J. (2006). Az írásmozgás-koordináció fejlesztése 4-8 éves életkorban. Mozaik Kiadó.

Molnár, B., Pálfi S., Szerepi S. \& Vargáné Nagy, A. (2015). Kisgyermekkori nevelés Magyarországon. Educatio,24(3),121-128.

Murányiné Sipőcz, Zs. (2001). Te leszel az én tanító nénim. Hogyan Tovább? (2), 15.

Nagy, A. (2018). Harmonikus óvoda-iskola átmenet határon innen és túl. Paideia, 6(1), 179-194. https://doi.org/10.33034/PAIDEIA.2018.6.1.179

Nagy, J. (1974a). Iskolaelőkészités és beiskolázás. Akadémiai Kiadó.

Nagy, J. (1974b). Kompenzáló beiskolázási modell. Akadémiai Kiadó.

Nagy, J. (1976). PREFER, preventív fejlettségvizsgáló rendszer 5-6 éves gyermekek iskolakészültségének mérése. MTA Pedagógiai Kutatócsoport.

Nagy, J. (1980). Az 5-6 éves gyermekeink iskolakészültsége. Akadémiai Kiadó.

Nagy, J. (1986). PREFER: Preventív fejlettségvizsgáló rendszer 4-7 éves gyermekek számára. Akadémiai Kiadó.

Nagy, J. (2003). Az eredményesebb képességfejlesztés feltételeiről és lehetőségeiről. Iskolakultúra,13(8), 40-52.

Nagy, J. (2008). Az alsó tagozatos oktatás megújítása. In Fazekas, K., Köllő, J. \& Varga, J. (Eds.), Zöld könyv a magyar közoktatás megújításáért 2008 (pp. 53-69). ECOSTAT.

Nagy, J. (2012). Oktatási rendszerünk jövője. Iskolakultúra, 22(3), 25-43. 
Nagy, J. (2009). Fejlesztés mesékkel: Az anyanyelv. a gondolkodás fejlesztésének segítése mesékkel a 4-8 éves életkorban. Mozaik Kiadó.

Nagy, J., Józsa, K., Vidákovich, T. \& Fazekasné Fenyvesi, M. (2004a). DIFER Programcsomag: Diagnosztikus fejlődésvizsgáló és kritériumorientált fejlesztő rendszer 4-8 évesek számára. Mozaik Kiadó.

Nagy, J., Józsa, K., Vidákovich, T. \& Fazekasné Fenyvesi, M. (2004b). Az elemi alapkészségek fejlödése 4-8 éves életkorban. Mozaik Kiadó.

Nagy, V. (2017). Óvodából iskolába. Pedagógiai és Módszertani Tanácsadó,3(9), $2-15$.

Nagy-Borús, E. (1998). Szeptemberi útravaló a szülőknek és az elsősöknek. Új Kép,2(7), 3.

Németh, M. (1993). Az óvodaiskola funkciója és szervezete. In Németh, M. \& Golobics, K. (Eds.), Óvodaiskolai program 1. (pp. 9-29). Iskolafejlesztési Alapítvány.

Nemzeti Alaptanterv (2012). 110/2012. (VI. 4.) Korm. rendelet a Nemzeti Alaptanterv kiadásáról, bevezetéséről és alkalmazásáról. Magyar Közlöny. 66.

Nemzeti Alaptanterv Tervezete (2018). https://www.oktatas2030.hu/wp-content/ uploads/2018/08/a-nemzeti-alaptanterv-tervezete_2018.08.31.pdf

Novák, G. (1998). Intenzív előkészítés. Köznevelés, 54(12), 12-13.

Nyitrai, Á. (2009). A mese, a mesélés fejlesztő hatása. In Nagy, J. (Ed.), Fejlesztés mesékkel. Az anyanyelv, a gondolkodás fejlődésének segítése mesékkel 4-8 éves életkorban (pp. 9-29). Mozaik Kiadó.

Nyitrai, Á. (2009). Mesék és fejlődéssegítő feladatok az 1. és a 2. osztályos olvasókönyvekben. Iskolakultúra, 19(11), 3-18.

Nyitrai, Á. (2016). Mese és mesélés. Iskolakultúra, 26(4), 75-83.

Nyitrai, Á. \& Darvai, S. (2013). A mese és a játék jelenléte a kisgyermekes családok életében. Iskolakultúra, 23(11), 73-85.

Nyitrai, Á. \& Zentai, G. (2012). Az összefüggés-kezelés fejlődésének segítése mesékkel 4-8 éves gyermekek körében. In Kozma, T. \& Perjés, I. (Eds.), Új kutatások a neveléstudományokban, 2011 (pp. 99-122).MTA Pedagógiai Tudományos Bizottsága.

Óvodai nevelés országos alapprogramja (1996). 137.1996. (VIII. 28.) Korm. rendelet az Óvodai Nevelés országos alapprogramjának kiadásáról.

Óvodai nevelés országos alapprogramja (2012). 363/2012. (XII. 17.) Korm. rendelet az Óvodai nevelés országos alapprogramjáról.

Páli, J. (1997). Óvoda-iskola átmenet. In Báthory, Z. \& Falus, I. (Eds,), Pedagógiai lexikon (pp. 93-94). Keraban Kiadó.

Pányiné Segesdi, N. (2004). Az óvoda-iskola közti átmenet segítése számítógépes környezetben. Esetleírás. Budapest: Országos Fejlesztő Intézet. https://ofi.oh.gov.hu/ az-ovoda-iskola-kozti-atmenet-segitese-szamitogepes-kornyezetben-esetleiras 
Pap, J. (2016). Lurkó iskola-elökészitő program. Módszertan. Novum Könyvklub.

Pászti, É. (2007). A jó iskolakezdés tényezőiről, feltételeitől, hátteréről - óvónői szemmel. Óvodai Nevelés, 60(5), 154-157.

Perlai, R. (2009). Az iskoláskor hajnalán. Az óvoda-iskola átmenet kérdései. Óvodai Nevelés, 62(7), 236-237.

Pintér, K. (2007). Az óvoda-iskola közötti átmenetet segítő program. Tanitó, 45(1), 10-12.

Porkolábné Balogh, K., Balázsné Szűcs, J. \& Szaitzné Gregorits, A. (1997). Komplex prevenciós óvodai program „kudarc nélkül az iskolában”. Volán Humán Oktatási és Szolgáltató Rt.

Pozsonyi, M. \& Tóthné Balogh, Á. (2005a). START óvodai fejlesztő program. Új Pedagógiai Szemle, 55(5), 72-84.

Pozsonyi, M. \& Tóthné Balogh, Á. (2005b). A START könnyítő óvodai program, azaz egy tíz éve müködő fejlesztő óvodai program bemutatása. Fejlesztő Pedagógia, 16(2-3), 106-112.

Reidl, K. (2012). Óvodaiskola "Vásárhelyi-módra” 6. Tanító Módszertani Folyóirat, (7), 11-13.

Rozsnyai, M. (2002). Képességfejlesztő játékok a Lépésről Lépésre programban. Közoktatás. 13(3), 6-7.

Schüttler, V. (1997). Mi is az az Ovi-Suli? Beszélgetés Baksay Lászlónéval, az Ovi-Suli vezetőjével. Új Pedagógiai Szemle, 47(7-8), 173-179.

Sóstói, P. (2003). Szemléletváltással az óvodából iskolába való átmenet zökkenőmentességért! In Kováts, D. (Ed.), Ködöböcz József emlékére (pp. 157163). Sárospataki Pedagógiai Füzetek.

Szabó, G. \& Gacsályi, L. (2013). Iskolakezdés másképp. Iskolatáska. Educatio: https://iskolataska.educatio.hu/index.php/jogyakorlatotlet/jogyak_print_show/ jogyakId/790/1580969681.edu

Szabó, M. (2005). Az iskola kezdő szakasz helyzetének feltárása. Új Pedagógiai Szemle, (3), 80-97.

Szabóné Sóvágó, J. (2011). Nyílt nap szülőknek, tanítóknak a sikeres iskolakezdésért. Óvodai Nevelés, 64(5-6), 30-32.

Szabóné Szél, J. (2004). Iskolamarketing a beiskolázás szolgálatában. In Szontagh, P. (Ed.), Kihívások és válaszok az általános iskolában (pp. 51-67). Ikerhold Kiadó és Pont Kiadó közös kiadása.

Szalayné Szöllősi, M. (1997). „0.” osztály a Józsefvárosban. Budapesti Nevelö, 33(1), 39-44.

Szalóky, B. (1994). Gondolatok a gyermekközpontú napközi otthonról. Mozaik Kiadó.

Szalontai, E., Kocsis, G., Kovács, S. \& Pap Szigetiné Németh, A. (2012). Óvodaiskola "Vásárhelyi-módra" 4. Tanító Módszertani Folyóirat, 50(4), 25-28.

Sz. Németh, I. (1993). Pedagógusok attitűdváltozása. In Németh, M. \& Golobics, K. (Eds.), Óvodaiskolai program 1 (pp. 45-49). Iskolafejlesztési Alapítvány. 
Szigetiné Sulyok, J. (2012). Szivárvány-híd, az óvoda-iskola átmenetet segítő program. Tanitás-tanulás szakmódszertani folyóirat - tanitók számára, 9(8) 41-43.

Tóth, I. \& Soósné Hűse, T. (2013). Legyen élmény az iskola. Iskolatáska. Educatio: https://iskolataska.educatio.hu/index.php/jogyakorlatotlet/jogyak_print_show/ jogyakId/782/1580974399.edu

Török, B. (2004). A gyermeküket óvodáztató szülők körében végzett országos felmérés eredményei. Felsőoktatási Kutató Intézet.

T. Pusztafalvi, H. (1993). Szülők az óvodaiskoláról. In Németh, M. \& Golobics, K. (Eds.), Óvodaiskolai program 1 (pp. 49-57). Iskolafejlesztési Alapítvány.

Vágásiné Vajda, R. (2012). „Hívogat az Eszterházy”: Beiskolázási program az egri Eszterházy Károly Főiskola Gyakorló Általános Iskolájában. Módszertani Közlemények, 55(4), 1-4.

Varga, I. (1996). Én így kezdem. Módszerekés tapasztalatoka tanulók megismeréséhez I. osztályban. Tanító Módszertani Folyóirat, 34(7), 9-10.

Veszprémi, J. \& Solymos, A. (2005). Beszoktatás? Avagy: a szemléletváltás első jele a kérdőjel. Újpesti Pedagógiai Szemle, 11(2), 9-13.

Villányi, J. (2018). NAT véleményezése. Kisgyermeknevelési Szakosztály. http:// pedagogiai-tarsasag.hu/wp-content/uploads/2018/09/NAT.pdf

Wesley, P. W. \& Buysse, V. (2003). Making meaning of school readiness in schools and communities. Early Childhood Research Quarterly. 18(3), 351-375.

Zentai, G. \& Józsa, K. (2012). Az elemi alapkészségek óvodáskori fejlettségének prediktív ereje az elsős készségfejlettségre: egy longitudinális vizsgálat eredményei. In Benedek, A, Tóth, P. \& Vedovatti, A. (Eds.), A munka és nevelés világa a tudományban. Program és Összefoglalók (pp. 154). XII. Országos Neveléstudományi Konferencia: MTA Pedagógiai Bizottság.

Zentai, G. \& Józsa, K. (2014). Óvodás gyermekek gondolkodási képességének fejlesztése: egy fejlesztő program módszerei és eredményei. Fejlesztő Pedagógia, 25(3), 9-14.

Zill, N. \& West, J. (2001). Entering kindergarten: Findings from the Condition of Education 2000 (NCES 2001-035). US Department of Education, Office of Educational Research and Development.

Zsíros, M. (1995). Folyamatos képességfejlesztés az Óvodaiskolában. Csengőszó, 3(4), 7-11.

Zsíros, M. (2012). Óvodaiskola "Vásárhelyi-módra” 2. Tanitó Módszertani Folyóirat, $50(2), 6-7$.

Zsoldos, M. (2009). Kognitív fejlesztő terápia a tanulási zavarok kezelésével. Brigitte Sindelar kognitív fejlesztőprogramja. In M. Tamás, M. (Ed.), Fejlesztőpedagógia (pp. 103-123). ELTE Eötvös Kiadó.

Zsolnai, A. (2006). A szocialitás fejlesztése 4-8 éves életkorban. Mozaik Kiadó. 


\section{1. függelék}

A feltárt óvoda-iskola átmenetet segítö gyakorlatok áttekintése a kidolgozó, a fókusz és a beágyazottság elemzés szempontok alapján ábécérendben

\begin{tabular}{|c|c|c|c|c|c|}
\hline \multirow[b]{2}{*}{ Szerző, év } & \multirow[b]{2}{*}{ Kidolgozó } & \multicolumn{2}{|c|}{ Fókusz } & \multicolumn{2}{|c|}{ Beágyazottság } \\
\hline & & $\begin{array}{l}\text { Képes- } \\
\text { ség-fej- } \\
\text { lesztés }\end{array}$ & $\begin{array}{l}\text { Ismerke- } \\
\text { dés }\end{array}$ & Elméleti & $\begin{array}{c}\text { Tartalmi } \\
\text { szabályo- } \\
\text { zó doku- } \\
\text { mentu- } \\
\text { mok }\end{array}$ \\
\hline $\begin{array}{l}\text { Alföldiné Hende et } \\
\text { al., } 2013\end{array}$ & $\begin{array}{l}\text { óvodapedagó- } \\
\text { gus }\end{array}$ & $\checkmark$ & & & $\checkmark$ \\
\hline $\begin{array}{l}\text { Bischofné Blandl et } \\
\text { al., } 2012\end{array}$ & tanító & & $\checkmark$ & & \\
\hline Bondor, 2019 & tanító & $\checkmark$ & & $\checkmark$ & \\
\hline Czihlár, 1997 & tanító & & $\checkmark$ & & \\
\hline Decsiné Lovasi, 1994 & tanító & & $\checkmark$ & & \\
\hline Deliné Fráter, 1997 & kutató & $\checkmark$ & $\checkmark$ & $\checkmark$ & \\
\hline Dömény, 2012 & $\begin{array}{l}\text { óvodapedagó- } \\
\text { gus és tanító }\end{array}$ & & $\checkmark$ & & \\
\hline Esztergomi, 2012 & tanító & & $\checkmark$ & & \\
\hline Fazekas, 2015 & tanító & & $\checkmark$ & & $\checkmark$ \\
\hline Gáspár, 1990 & kutató & $\checkmark$ & $\checkmark$ & $\checkmark$ & \\
\hline Gráczer, 2013 & tanító & & $\checkmark$ & & $\checkmark$ \\
\hline Hamrák, 1994 & tanító & $\checkmark$ & $\checkmark$ & $\checkmark$ & \\
\hline Kócza, 1995 & tanító & & $\checkmark$ & & \\
\hline Kósáné Ormai, 2017 & tanító & & $\checkmark$ & & $\checkmark$ \\
\hline $\begin{array}{l}\text { Kovács \& Kakuk, } \\
2013\end{array}$ & $\begin{array}{l}\text { óvodapedagó- } \\
\text { gus és tanító }\end{array}$ & $\checkmark$ & & & \\
\hline Kovácsné Pap, 2010 & tanító & & $\checkmark$ & & \\
\hline $\begin{array}{l}\text { Kozákné Szentgyör- } \\
\text { gyi, } 2011\end{array}$ & tanító & & $\checkmark$ & & \\
\hline Kőrösné Mikis, 2006 & tanító & $\checkmark$ & & $\checkmark$ & \\
\hline Krajcsi, 2000 & tanító & $\checkmark$ & & & \\
\hline Kutiné Adorján, 1990 & tanító & $\checkmark$ & $\checkmark$ & $\checkmark$ & \\
\hline Lovrity, 1984 & $\begin{array}{l}\text { óvodapedagó- } \\
\text { gus és tanító }\end{array}$ & & $\checkmark$ & & \\
\hline Murányi Sipőcz, 2002 & tanító & $\checkmark$ & & & \\
\hline Nagy, 2017 & $\begin{array}{l}\text { óvodapedagó- } \\
\text { gus és tanító }\end{array}$ & & $\checkmark$ & & \\
\hline
\end{tabular}


A hazai publikált óvoda-iskola átmenetet segítő gyakorlatok

szisztematikus áttekintése

\begin{tabular}{|c|c|c|c|c|c|}
\hline Nagy et al. 2004a & kutató & $\checkmark$ & & $\checkmark$ & \\
\hline Nagy-Borús, 1998 & pszichológus & & $\checkmark$ & & \\
\hline Novák, 1998 & $\begin{array}{l}\text { óvodapedagó- } \\
\text { gus }\end{array}$ & $\checkmark$ & $\checkmark$ & $\checkmark$ & \\
\hline Pálfi, 2019 & $\begin{array}{l}\text { óvodapedagó- } \\
\text { gus }\end{array}$ & & $\checkmark$ & & \\
\hline Pányiné Segesdi, 2004 & $\begin{array}{l}\text { óvodapedagó- } \\
\text { gus és tanító }\end{array}$ & & $\vee$ & & \\
\hline Pap, 2016 & $\begin{array}{l}\text { óvodapedagó- } \\
\text { gus }\end{array}$ & $\checkmark$ & & & \\
\hline Pintér, 2007 & $\begin{array}{l}\text { óvodapedagó- } \\
\text { gus és tanító }\end{array}$ & & $\checkmark$ & $\checkmark$ & \\
\hline $\begin{array}{l}\text { Porkolábné Balogh et } \\
\text { al., } 1997\end{array}$ & kutató & $\checkmark$ & & $\checkmark$ & \\
\hline $\begin{array}{l}\text { Pozsonyi \& } \\
\text { Tóthné Balogh, 2005a; } \\
\text { 2005b }\end{array}$ & $\begin{array}{l}\text { óvodapeda- } \\
\text { gógus, fejlesz- } \\
\text { tő- és gyógy- } \\
\text { pedagógusok, } \\
\text { pszichológu- } \\
\text { sok }\end{array}$ & $\checkmark$ & & $\checkmark$ & \\
\hline Sóstói, 2002 & tanító & & $\checkmark$ & & \\
\hline $\begin{array}{l}\text { Szabó \& Gacsályi, } \\
2013\end{array}$ & tanító & & $\checkmark$ & & $\checkmark$ \\
\hline Szabóné Sóvágó, 2011 & $\begin{array}{l}\text { óvodapedagó- } \\
\text { gus }\end{array}$ & & $\vee$ & & \\
\hline Szabóné Szél, 2002 & tanító & & $\checkmark$ & & \\
\hline $\begin{array}{l}\text { Szalayné Szöllősi, } \\
1997\end{array}$ & tanító & $\checkmark$ & $\checkmark$ & $\checkmark$ & \\
\hline Szalóky, 1994 & tanító & & $\checkmark$ & & \\
\hline $\begin{array}{l}\text { Szigetiné Sulyok, } \\
2012\end{array}$ & tanító & $\checkmark$ & & & \\
\hline $\begin{array}{l}\text { Tóth \& Soósné Hűse, } \\
2013\end{array}$ & $\begin{array}{l}\text { óvodapedagó- } \\
\text { gus }\end{array}$ & & $\checkmark$ & & $\checkmark$ \\
\hline Vágásiné Vajda, 2012 & tanító & & $\checkmark$ & & \\
\hline Varga, 1996 & tanító & & $\checkmark$ & & \\
\hline
\end{tabular}




\section{2. függelék}

A feltárt óvoda-iskola átmenetet segitö gyakorlatok áttekintése a müködési feltételeik alapján ábécérendben

\begin{tabular}{|c|c|c|c|c|c|c|}
\hline \multirow[b]{3}{*}{ Szerző, év } & \multicolumn{6}{|c|}{ Müködési feltételek } \\
\hline & \multicolumn{4}{|c|}{ Személyi } & \multicolumn{2}{|c|}{ Tárgyi } \\
\hline & $\begin{array}{l}\text { Együtt- } \\
\text { mülö- } \\
\text { dés }\end{array}$ & $\begin{array}{l}\text { Tovább- } \\
\text { képzés }\end{array}$ & $\begin{array}{l}\text { Kétta- } \\
\text { nítós } \\
\text { modell }\end{array}$ & $\begin{array}{l}\text { Kétdip- } \\
\text { lomás } \\
\text { pedagó- } \\
\text { gus }\end{array}$ & $\begin{array}{l}\text { Eszköz- } \\
\text { igény }\end{array}$ & $\begin{array}{l}\text { Tér-ren- } \\
\text { dezés }\end{array}$ \\
\hline $\begin{array}{l}\text { Alföldiné Hende et } \\
\text { al., } 2013\end{array}$ & & & & & $\checkmark$ & \\
\hline $\begin{array}{l}\text { Bischofné Blandl et } \\
\text { al., } 2012\end{array}$ & $\checkmark$ & & & & & \\
\hline Bondor, 2019 & & & & & $\checkmark$ & \\
\hline Czihlár, 1997 & $\checkmark$ & & & & & \\
\hline Decsiné Lovasi, 1994 & $\checkmark$ & & & & & $\checkmark$ \\
\hline Deliné Fráter, 1997 & $\checkmark$ & $\checkmark$ & $\checkmark$ & & $\checkmark$ & $\checkmark$ \\
\hline Dömény, 2012 & $\checkmark$ & & & & & \\
\hline Esztergomi, 2012 & $\checkmark$ & & & & & \\
\hline Fazekas, 2015 & $\checkmark$ & & & & & \\
\hline Gáspár, 1990 & $\checkmark$ & & & $\checkmark$ & $\checkmark$ & $\checkmark$ \\
\hline Gráczer, 2013 & $\checkmark$ & & & & $\checkmark$ & \\
\hline Hamrák, 1994 & & & & & $\checkmark$ & \\
\hline Kócza, 1995 & $\checkmark$ & & & & & \\
\hline Kósáné Ormai, 2017 & $\checkmark$ & & & & & $\checkmark$ \\
\hline $\begin{array}{l}\text { Kovács \& Kakuk, } \\
2013\end{array}$ & $V$ & & & & & \\
\hline Kovácsné Pap, 2010 & $\checkmark$ & & & & & \\
\hline $\begin{array}{l}\text { Kozákné Szentgyör- } \\
\text { gyi, } 2011\end{array}$ & $V$ & & & & & \\
\hline Kőrösné Mikis, 2006 & & & & & $\checkmark$ & \\
\hline Krajcsi, 2000 & $\checkmark$ & & & & & \\
\hline Kutiné Adorján, 1990 & $\checkmark$ & & & & $\checkmark$ & \\
\hline Lovrity, 1984 & $\checkmark$ & & & & & \\
\hline Murányi Sipőcz, 2002 & $\checkmark$ & & & & & \\
\hline Nagy, 2017 & $\checkmark$ & & & & & \\
\hline Nagy et al., 2004a & & $\checkmark$ & & & $\checkmark$ & \\
\hline
\end{tabular}


A hazai publikált óvoda-iskola átmenetet segítő gyakorlatok szisztematikus áttekintése

\begin{tabular}{|l|c|l|l|l|l|l|}
\hline Nagy-Borús, 1998 & $\checkmark$ & & & & & \\
\hline Novák, 1998 & $\checkmark$ & & & & & $\checkmark$ \\
\hline Pálfi, 2019 & $\checkmark$ & & & & & \\
\hline Pányiné Segesdi, 2004 & $\checkmark$ & & & & & \\
\hline Pap, 2016 & & & & & $\checkmark$ & \\
\hline Pintér, 2007 & $\checkmark$ & & $\checkmark$ & & & \\
\hline $\begin{array}{l}\text { Porkolábné Balogh et } \\
\text { al., 1997 }\end{array}$ & & & & & $\checkmark$ & \\
\hline $\begin{array}{l}\text { Pozsonyi \& Tóthné } \\
\text { Balogh, 2005a; 2005b }\end{array}$ & & & & & & \\
\hline Sóstói, 2002 & & & & & & \\
\hline $\begin{array}{l}\text { Szabó \& Gacsályi, } \\
\text { 2013 }\end{array}$ & & & & & & \\
\hline Szabóné Sóvágó, 2011 & $\checkmark$ & & & & & \\
\hline Szabóné Szél, 2002 & $\checkmark$ & & & & & \\
\hline $\begin{array}{l}\text { Szalayné Szöllósi, } \\
\text { 1997 }\end{array}$ & & & & & & \\
\hline Szalóky, 1994 & & & & & & \\
\hline $\begin{array}{l}\text { Szigetiné Sulyok, } \\
2012\end{array}$ & & & & & & \\
\hline $\begin{array}{l}\text { Tóth \& Soósné Hüse, } \\
2013\end{array}$ & $\checkmark$ & & & & \\
\hline Vágásiné Vajda, 2012 & $\checkmark$ & & & & \\
\hline Varga, 1996 & & & & & \\
\hline
\end{tabular}




\section{3. függelék}

A feltárt óvoda-iskola átmenetet segítö gyakorlatok áttekintése a lefedett idöszak és a hatásvizsgálat elemzési szempontok alapján ábécérendben

\begin{tabular}{|c|c|c|c|c|}
\hline \multirow[b]{2}{*}{ Szerző, év } & \multicolumn{3}{|c|}{ Lefedett időszak } & \multirow[b]{2}{*}{$\begin{array}{l}\text { Hatásvizs- } \\
\text { gálat }\end{array}$} \\
\hline & Óvoda & Iskola & $\begin{array}{l}\text { Óvoda és } \\
\text { iskola kö- } \\
\text { zött }\end{array}$ & \\
\hline Alföldiné Hende et al., 2013 & $\checkmark$ & & & \\
\hline Bischofné Blandl et al., 2012 & $\checkmark$ & & & \\
\hline Bondor, 2019 & & $\checkmark$ & & \\
\hline Czihlár, 1997 & $\checkmark$ & $\checkmark$ & & \\
\hline Decsiné Lovasi, 1994 & $\checkmark$ & $\checkmark$ & & \\
\hline Deliné Fráter, 1997 & $\checkmark$ & $\checkmark$ & & $\checkmark$ \\
\hline Dömény, 2012 & $\checkmark$ & $\checkmark$ & & \\
\hline Esztergomi, 2012 & $\checkmark$ & $\checkmark$ & & \\
\hline Fazekas, 2015 & $\checkmark$ & & & \\
\hline Gáspár, 1990 & $\checkmark$ & $\checkmark$ & & $\checkmark$ \\
\hline Gráczer, 2013 & & $\checkmark$ & & \\
\hline Hamrák, 1994 & & $\checkmark$ & & \\
\hline Kócza, 1995 & & $\checkmark$ & & \\
\hline Kósáné Ormai, 2017 & $\checkmark$ & $\checkmark$ & & \\
\hline Kovács \& Kakuk, 2013 & & & $\checkmark$ & \\
\hline Kovácsné Pap, 2010 & $\checkmark$ & & & \\
\hline Kozákné Szentgyörgyi, 2011 & $\checkmark$ & & & \\
\hline Körösné Mikis, 2006 & & $\checkmark$ & & \\
\hline Krajcsi, 2000 & & & $\checkmark$ & \\
\hline Kutiné Adorján, 1990 & $\checkmark$ & $\checkmark$ & & \\
\hline Lovrity, 1984 & $\checkmark$ & & & \\
\hline Murányi Sipőcz, 2002 & $\checkmark$ & $\checkmark$ & & \\
\hline Nagy, 2017 & $\checkmark$ & $\checkmark$ & & \\
\hline Nagy et al., 2004a & $\checkmark$ & $\checkmark$ & & $\checkmark$ \\
\hline Nagy-Borús, 1998 & & $\checkmark$ & & \\
\hline Novák, 1998 & & & $\checkmark$ & \\
\hline Pálfi, 2019 & & $\checkmark$ & & \\
\hline Pányiné Segesdi, 2004 & $\checkmark$ & & & \\
\hline Pap, 2016 & $\checkmark$ & & & \\
\hline
\end{tabular}


A hazai publikált óvoda-iskola átmenetet segítő gyakorlatok szisztematikus áttekintése

\begin{tabular}{|l|c|c|c|c|}
\hline Pintér, 2007 & & $\checkmark$ & & \\
\hline $\begin{array}{l}\text { Porkolábné Balogh et al., } \\
1997\end{array}$ & $\checkmark$ & & \\
\hline $\begin{array}{l}\text { Pozsonyi \& Tóthné Balogh, } \\
\text { 2005a, 2005b }\end{array}$ & $\checkmark$ & & \\
\hline Sóstói, 2002 & & $\checkmark$ & & \\
\hline Szabó \& Gacsályi, 2013 & $\checkmark$ & & & \\
\hline Szabóné Sóvágó, 2011 & $\checkmark$ & $\checkmark$ & & \\
\hline Szabóné Szél, 2002 & $\checkmark$ & $\checkmark$ & & \\
\hline Szalayné Szöllősi, 1997 & & & & \\
\hline Szalóky, 1994 & & $\checkmark$ & & \\
\hline Szigetiné Sulyok, 2012 & & $\checkmark$ & & \\
\hline Tóth \& Soósné Hűse, 2013 & & & & \\
\hline Vágásiné Vajda, 2012 & $\checkmark$ & & & \\
\hline Varga, 1996 & $\checkmark$ & $\checkmark$ & & \\
\hline
\end{tabular}




\section{Fleisz-Gyurcsik, A.}

\section{A systemic review of Hungarian literature on practices that assist transition from kindergarten to school}

International and Hungarian literature describes a number of practices to ease the transition from kindergarten to school, but the reactions of Hungarian researchers to these are as yet unknown. The purpose of my review is therefore to systematically collect and analyze published Hungarian kindergarten-to-school transition-assisting practices. In my study I identified 42 practices published in the Hungarian literature before March 2020 and I analyzed them from 7 angles. Thus, it became evident that most of them were developed by professional educators and were published in the mid-2000s. They are mainly intended to inform new institutions and future educators. The most characteristic feature is that the authors do not embed their work in a theoretical context. They emphasize personal factors rather than instrumental-environmental conditions. The practices I found encompass various time intervals of the transition; most commonly they encompass an entire year in the last year of kindergarten. In the case of most practices I found no reference to an impact study.

Keywords: kindergarten-to-school transition, starting school, systemic review

FLeisz-Gyurcsik Anita: https://orcid.org/0000-0003-4353-2720 